\title{
NamZ1 and NamZ2 from the oral pathogen Tannerella forsythia are peptidoglycan processing exo- $\beta$ - $N$-acetylmuramidases with distinct substrate specificity
}

Marina Borisova ${ }^{\mathrm{a}}$, Katja Balbuchta ${ }^{\mathrm{a}}$, Andrew Lovering ${ }^{\mathrm{b}}$, Alexander Titz ${ }^{\mathrm{c}, \mathrm{d}, \mathrm{e}}$, Christoph Mayer $^{\mathrm{a} \#}$

Author affiliations:

${ }^{a}$ Interfaculty Institute of Microbiology and Infection Medicine, Organismic Interactions/Glycobiology, Eberhard Karls Universität Tübingen, Tübingen, Germany

binstitute of Microbiology and Infection, School of Biosciences, University of Birmingham, Birmingham, UK

${ }^{\mathrm{c} C h e m i c a l ~ B i o l o g y}$ of Carbohydrates, Helmholtz Institute for Pharmaceutical Research Saarland, Helmholtz Centre for Infection Research, Saarbrücken, Germany

${ }^{\mathrm{d} D e u t s c h e s ~ Z e n t r u m ~ f u ̈ r ~ I n f e k t i o n s f o r s c h u n g ~(D Z I F), ~ S t a n d o r t ~ H a n n o v e r-B r a u n s c h w e i g, ~ G e r m a n y ~}$

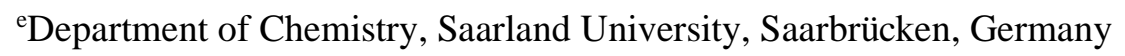

\#Address correspondence to: Christoph Mayer, Interfaculty Institute of Microbiology and Infection Medicine, Microbiology/Glycobiology, University of Tübingen, Auf der Morgenstelle 28, 72076 Tübingen, Germany: christoph.mayer@uni-tuebingen.de; Tel.: +49 (7071) 29-74645

Running title: Exo- $\beta$ - $N$-acetylmuramidases from $T$. forsythia

Keywords: $N$-acetylmuramic acid (MurNAc), MurNAc auxotrophy, pNP-MurNAc, Bacteroidetes, peptidoglycan salvage, cell wall recycling, exo-lytic muramidase, disaccharidase, CAZy glycosidase, family GH171, glycoside hydrolase, carbohydrate metabolism 


\section{ABSTRACT}

The Gram-negative periodontal pathogen Tannerella forsythia is inherently auxotrophic for $N$ acetylmuramic acid (MurNAc), which is an essential carbohydrate constituent of the peptidoglycan (PGN) of the bacterial cell wall. Thus, to build up its cell wall, T. forsythia strictly depends on the salvage of exogenous MurNAc or sources of MurNAc, such as polymeric or fragmentary PGN, derived from cohabiting bacteria within the oral microbiome. In our effort to elucidate how T. forsythia satisfies its demand for MurNAc, we recognized that the organism possesses three putative orthologs of the exo- $\beta$ $N$-acetylmuramidase BsNamZ from Bacillus subtilis, which cleaves non-reducing end, terminal MurNAc entities from the artificial substrate pNP-MurNAc and the naturally-occurring disaccharide substrate MurNAc- $\beta-1,4-N$-acetylglucosamine (GlcNAc). TfNamZ1 and TfNamZ2 were successfully purified as soluble, pure recombinant His6-fusions and characterized as exo-lytic $\beta$ - $N$-acetylmuramidases with distinct substrate specificities. The activity of TfNamZ1 was considerably lower compared to TfNamZ2 and BsNamZ, in the cleavage of pNP-MurNAc and MurNAc-GlcNAc. When peptide-free PGN glycans were used as substrates, we revealed striking differences in the specificity and mode of action of these enzymes, as analyzed by mass spectrometry. TfNamZ1, but not TfNamZ2 or BsNamZ, released GlcNAcMurNAc disaccharides from these glycans. In addition, glucosamine (GlcN)-MurNAc disaccharides were generated when partially N-deacetylated PGN glycans from B. subtilis 168 were applied. This characterizes TfNamZ1 as a unique disaccharide-forming exo-lytic $\beta$ - $N$-acetylmuramidase (exodisaccharidase), and, TfNamZ2 and BsNamZ as sole MurNAc monosaccharide-lytic exo- $\beta-N$ acetylmuramidases.

\section{IMPORTANCE}

Two exo- $\beta-N$-acetylmuramidases from $T$. forsythia belonging to glycosidase family GH171 (www.cazy.org) were shown to differ in their activities, thus revealing a functional diversity within this 
family: NamZ1 releases disaccharides (GlcNAc-MurNAc/GlcN-MurNAc) from the non-reducing ends of PGN glycans, whereas NamZ2 releases terminal MurNAc monosaccharides. This work provides a better understanding of how T. forsythia may acquire the essential growth factor MurNAc by the salvage of PGN from cohabiting bacteria in the oral microbiome, which may pave avenues for the development of anti-periodontal drugs. On a broad scale, our study indicates that the utilization of PGN as a nutrient source, involving exo-lytic $N$-acetylmuramidases with different modes of action, appears to be a general feature of bacteria, particularly among the phylum Bacteroidetes.

\section{INTRODUCTION}

The net-shaped heteropolymer peptidoglycan $(\mathrm{PGN})$ is the major structural component of the cell wall of bacteria, conferring physical strength to the cells. It is composed of $\beta$-1,4-linked glycan chains of alternating $N$-acetylmuramic acid (MurNAc) and $N$-acetylglucosamine (GlcNAc) monosaccharides, which are interconnected via oligopeptides attached to MurNAc [Walter, 2019 \#19888]. The PGN cell wall is continuously degraded and remodelled during bacterial growth and differentiation (i.e., PGN turnover), a process that involves the combined activity of potentially autolytic enzymes (autolysins), including endo-cleaving $\mathrm{N}$-acetylmuramidases, $\mathrm{N}$-acetylglucosaminidases, and lytic transglycosidases [Oshida, 1995 \#15478;Mayer, 2012 \#13163;Dik, 2017 \#16124]. Since the synthesis and integrity of the PGN is essential for bacteria to cope with environmental stresses, antibacterial-acting endo-lytic PGN glycosidases that ultimately cause bacterial lysis, such as endo- $N$-acetylmuramidases, commonly known as lysozymes, represent basal factors of innate immunity against bacterial infections [Ragland, 2017 \#19745].

The process of PGN turnover and utilization as a nutrient and energy source (i.e., PGN recycling or salvage), also involves the activity of exo-lytic hydrolases, which processively degrade PGN from the 
ends, thereby averting uncontrolled autolysis [Litzinger, 2010 \#12434]. We previously showed that Bacillus subtilis is able to digest intact PGN by sequential hydrolysis from the non-reducing ends via the joined activity of the exo- $\beta-N$-acetylglucosamidase BsNagZ, the exo- $N$-acetylmuramoyl-L-alanine amidase AmiE, and the exo-lytic $N$-acetylmuramidase BsNamZ, which sequentially release GlcNAc, peptides, and MurNAc, respectively [Litzinger, 2010 \#12434; Müller, 2021 \#18933]. Presumably, these hydrolases are involved in the degradation of PGN during turnover of the cell wall or the decay of lysed cells in a starving population of B. subtilis [Borisova, 2016 \#14239].

The exo-lytic $\beta$ - $N$-acetylmuramidase BsNamZ, was recently characterized and shown to constitute a novel family of glycosidases (CAZy GH171; www.cazy.org/GH171.html) [Müller, 2021 \#18933]. BsNamZ uniquely cleaves terminal $N$-acetylmuramic acid (MurNAc) moieties from the nonreducing ends (exo-lytic cleavage) of peptide-free, PGN glycans and also hydrolyzes the artificial substrate 4-nitrophenyl $\beta$-MurNAc (pNP-MurNAc). Thus, the activity of BsNamZ differs from lysozyme-like endo- $N$-acetylmuramidases (CAZy GH25), which are unable to cleave terminal MurNAc residues but hydrolyze internal glycosidic bonds within the PGN network (endo-lytic cleavage) and generally require peptide-substituted MurNAc residues [Ragland, 2017 \#19745].

We previously recognized that putative NamZ orthologs are narrowly distributed within bacteria and are frequently found within members of the Bacteroidetes phylum [Müller, 2021 \#18933]. The oral pathogen Tannerella forsythia, which is strongly associated with disease, such as periodontitis and rheumatoid arthritis, belongs to the Bacteroidetes [Loyola-Rodriguez, 2010 \#19862;Martinez-Rivera, 2017 \#19873;Bourgeois, 2019 \#19864]. Intriguingly, this organism is a natural auxotroph for MurNAc [Wyss, 1989 \#9982]. Since T. forsythia constitutes a classical Gram-negative PGN cell wall [Mayer, $2019 \# 16115]$, it strictly depends on a supply of MurNAc, for growth in axenic culture, or sources of MurNAc, which may be provided by other bacteria, to proliferate in the oral habitat [Wyss, 1989 \#9982;Hottmann, 2018 \#14525;Hottmann, 2021 \#19871]. Salvage of MurNAc from the medium, 
requires the MurNAc-specific inner membrane transporter TfMurT of T. forsythia [Ruscitto, 2016 \#14240]. In addition, T. forsythia imports PGN-derived disaccharides, particularly GlcNAc-MurNAc and GlcNAc-1,6-anhydroMurNAc, and possibly also muropeptides, via the recently identified transporter TfAmpG [Ruscitto, 2018 \#16099;Mayer, 2020 \#18932]. The latter transporter was recently shown to be is required for the utilization of polymeric PGN as a nutrient source by $T$. forsythia [Mayer, 2020 \#18932]. However, so far, the T. forsythia enzymes responsible for the release of MurNAc and MurNAc-containing disaccharides from PGN have remained unknown.

T. forsythia is able to utilize polymeric or fragmentary PGN to satisfy its need for MurNAc [Ruscitto, 2017 \#16112;Ruscitto, 2018 \#16099;Mayer, 2020 \#18932;Hottmann, 2021 \#19871]. Intriguingly, we recognized that $T$. forsythia harbours three putative namZ orthologs on its chromosome, which we named TfNamZ1-3 [Hottmann, 2021 \#19871]. It is reasonable to assume that these NamZ enzymes may be critical for the organism to liberate the essential growth factor MurNAc, however, likely they do not all serve the same purpose. Thus we aimed to elucidate the activities and substrate specificities of the NamZ orthologs from T. forsythia. Here we present the characterization of two of them and show that, despite of their high amino acid sequence identity, TfNamZ1 and TfNamZ2 differ in their substrate specificity and product formation. TfNamZ1 is an exo- $\beta-N$-acetylmuramidase that releases primarily GlcNAc-MurNAc from the non-reducing end of peptide-free PGN glycan strands, whereas TfNamZ2 releases MurNAc from the non-reducing ends of the glycans and thus, possesses classical exo- $\beta-N$-acetylmuramidase activity, similar to that previously described for BsNamZ [Müller, 2021 \#18933]. Interestingly, TfNamZ1 is encoded within a putative operon in the T. forsythia genome that also contains the genes encoding TfMurT and TfAmpG, as well as a number of other enzymes related to PGN salvage (Fig. 1). Thus, TfNamZ1 and TfNamZ2, yield the substrates of the transporters TfAmpG and TfMurT, respectively, thereby satisfying T. forsythia's need for the crucial growth factor MurNAc. 


\section{RESULTS}

\section{Identification of three putative NamZ orthologs from $T$. forsythia}

A BLAST search, using the amino acid sequence of the exo- $\beta-N$-acetylmuramidase BsNamZ [Müller, 2021 \#18933], identified three putative orthologs (DUF1343 family proteins; http://pfam.xfam.org/) in the T. forsythia ATCC 43037 proteome, which we named TfNamZ1 (Tanf_08370), TfNamZ2 (Tanf_00660), and TfNamZ3 (Tanf_00855). They display overall amino acid sequence identities of 46.8\%, 36.0\% and 37.4\%, respectively, to BsNamZ [Hottmann, $2021 \# 19871]$. In addition, the BLAST search revealed two NamZ-like DUF1343 family proteins from the phylogenetically related Bacteroides fragilis strain NCTC 9343 (BF9343_0362 and BF9343_0369), for which high resolution crystal structures have been determined (www.rcsb.org; PDB-IDs: 4K05 and 4JJA). These proteins, named BfNamZ1 and BfNamZ2, share $43.0 \%$ and $41.2 \%$ overall amino acid identity with BsNamZ, respectively. A multiple amino acid sequence alignment and a phylogenetic tree of the different putative NamZ orthologs from T. forsythia, B. fragilis and B. subtilis is depicted in Figure S1 (see Supplemental Material). The phylogenetic tree revealed that TfNamZ1, and BfNamZ1 form a branch and a second branch includes BfNamZ2 and the T. forsythia orthologs TfNamZ2 and TfNamZ3. This indicated BsNamZ-related functions of TfNamZ1 and BfNamZ2, and potentially somewhat distinct functions of TfNamZ2, TfNamZ3 and BfNamZ2, although prediction of variations in function is difficult solely on the basis of primary amino acid sequence.

To obtain some hints regarding their function, we analyzed the genomic organization of the three NamZ-encoding genes of T. forsythia (Fig. 1). TfnamZ1 is located within a large putative operon attributed to the catabolism/recycling of MurNAc and PGN-derived disaccharides, between the coding gene of the recently characterized GlcNAc-MurNAc/GlcNAc-anhMurNAc transporter TfAmpG [Ruscitto, 2017 \#16112; Mayer, 2020 \#18932] and the three genes encoding the MurNAc-transporter 
TfMurT [Ruscitto, 2016 \#14240], the MurNAc kinase TfMurK [Hottmann, 2018 \#14525], and the MurNAc 6-phosphate lactyl ether hydrolase TfMurQ [Ruscitto, 2016 \#14240]. Thus, the genomic organization of TfNamZ1 indicated a function related to PGN catabolism and suggested that TfNamZ1 may play a role in the formation of substrates of the TfMurT and TfAmpG transporters [Hottmann, 2021 \#19871]. In contrast, the genomic context of TfnamZ2 and TfnamZ3 did not allow any conclusions on their cellular function. Interestingly, the coding genes of the two NamZs from B. fragilis are both located within a gene cluster that resembles the TfnamZ1 operon (cf. Fig. 1) and, thus, likely play a role in PGN recycling/catabolism as well.

\section{TfNamZ1 and TfNamZ2 are exo- $\beta-N$-acetylmuramidases that hydrolyse pNP-MurNAc and MurNAc-GIcNAc}

To compare their activities, substrate specificities and biochemical functions, we cloned and heterologously overexpressed the three TfNamZ enzymes recombinantly. A first attempt to purify the recombinant proteins failed, due to the insolubility of the full length forms (data not shown). However, with the aid of the multiple amino acid sequence alignment (Fig. S1) and signal peptide predictions (Signal P 5.0), we realized that all three TfNamZs proteins contain putative signal sequences for protein secretion. We thus constructed recombinant proteins that lack the putative signal sequences (see Table $\mathrm{S} 1$ for a full list of the used primers) and this led to successful expression of the recombinant C-terminal His6 fusion proteins (Fig. S2). Subsequently, TfNamZ1 and TfNamZ2 were purified to apparent homogeneity using Ni-affinity chromatography and gel filtration, as demonstrated by SDS-PAGE (Fig. $\mathrm{S} 2$ ). The molecular weights of these proteins were in agreement with the expected size of $45.8 \mathrm{kDa}$ and 43.3 kDa, respectively. The protein yields from three independent purifications were in the range of 20 to $23 \mathrm{mg} / \mathrm{L}$ for TfNamZ1 and TfNamZ2. For so far unknown reasons, we failed to isolate TfNamZ3, either with or without putative signal sequence. Thus, we restricted our studies to the functional 
characterization of TfNamZ1 and TfNamZ2, but excluded TfNamZ3 from further biochemical investigation.

The exo- $\beta-N$-acetylmuramidase BsNamZ has previously been shown to hydrolyse solely the chemically synthesized, chromogenic substrate pNP-MurNAc, whereas the exo- $\beta-\mathrm{N}-$ acetylglucosaminidase BsNagZ hydrolyses exclusively pNP-GlcNAc [Litzinger, 2010 \#12434; Litzinger, 2010 \#12680;Müller, 2021 \#18933]. We first analyzed whether the recombinant TfNamZ1 and TfNamZ2 proteins also specifically cleave pNP-MurNAc. This was indeed the case, as visualized by the development of the yellow colored reaction product, i.e., the release of para-nitrophenol from pNP-MurNAc (Fig. 2). Both T. forsythia enzymes did not cleave pNP-GlcNAc, which indicates that they are specific exo- $\beta-N$-acetylmuramidases, such as BsNamZ (Fig. 2). Notably, the reaction of TfNamZ1 with pNP-MurNAc was considerably slower as compared to TfNamZ2 and BsNamZ when identical enzyme concentrations were applied, which indicates that TfNamZ1 is a less efficient exo- $\beta-N$ acetylmuramidase for the cleavage of the chromogenic pNP-MurNAc substrate.

We next analyzed whether TfNamZ1 and TfNamZ2 can also cleave the PGN-derived disaccharide MurNAc-GlcNAc, which constitutes the minimal natural substrate of the exo- $\beta-N$ acetylmuramidase BsNamZ [Müller, 2021 \#18933]. MurNAc-GlcNAc was obtained by enzymatic digestion of PGN from $S$. aureus with recombinant Atl $N$-acetylmuramyl-L-Ala amidase SaAtl ${ }^{\mathrm{AM}}$ and recombinant Atl $N$-acetylglucosaminidase SaAtl ${ }^{\text {Glc }}$ [Oshida, 1995 \#15478;Nega, 2020 \#19874]. LC-MS analyses revealed that Atl releases not only the disaccharide MurNAc-GlcNAc, which is the main carbohydrate product, as recently described [Nega, 2020 \#19874], but also the trisaccharide GlcNAcMurNAc-GlcNAc in about 15 times lower abundance (data not shown). To increase the amount of MurNAc-GlcNAc in the preparation, we further digested the trisaccharide containing Atl-hydrolysate with the exo- $\beta-N$-acetylglucosaminidase BsNagZ, thereby generating MurNAc-GlcNAc and GlcNAc. This MurNAc-GlcNAc preparation was then used as a substrate to test the activity of TfNamZ1 and 
TfNamZ2 by LC-MS analysis. The exact monoisotopic masses of the proton adducts $\left([\mathrm{M}+\mathrm{H}]^{+}\right)$of the investigated PGN metabolites MurNAc-GlcNAc (substrate), MurNAc and GlcNAc (products) are listed in Table S3. The MurNAc-GlcNAc preparation contained only minor amounts of MurNAc and GlcNAc prior to enzymatic incubation (Fig. 3). The incubation with TfNamZ2 and BsNamZ overnight at $37^{\circ} \mathrm{C}$ led to a complete degradation of the disaccharide and the respective formation of the monosaccharides MurNAc and GlcNAc (Fig. 3). Surprisingly, however, when the same amount of TfNamZ1 was added, only about half of the MurNAc-GlcNAc substrate was digested and consequently also only about half of the amounts of the products were generated (Fig. 3). Thus, TfNamZ1 has considerably lower activity with both substrates, MurNAc-GlcNAc and pNP-MurNAc. Neither TfNamZ1 nor TfNamZ2 were able to hydrolyze GlcNAc-MurNAc, as shown by LC-MS analysis (Fig. S3). In contrast, the disaccharide GlcNAc-MurNAc was completely degraded by the exo- $N$-acetylglucosaminidase BsNagZ, yielding GlcNAc and MurNAc (Fig. S3).

\section{TfNamZ1 releases GIcNAc-MurNAc disaccharides from peptide-free PGN glycans}

Differences in the activities of the two TfNamZs with the pNP-MurNAc and MurNAc-GlcNAc indicated that the proteins may have distinct substrate preferences. Therefore, we compared the activities of TfNamZ1 and TfNamZ2 using peptide-free PGN glycans. For this purpose, we generated short strands of peptide-free PGN glycans with varying length by digestion of S. aureus PGN with the Atl ${ }^{\mathrm{AM}}$ amidase, as described [Oshida, $1995 \# 15478$; Nega, 2020 \#19874]. When TfNamZ1 was added to the S. aureusderived glycan strands, a main product with $[\mathrm{M}+\mathrm{H}]^{+}=497.198 \mathrm{~m} / \mathrm{z}$, corresponding to a disaccharide containing the sugars GlcNAc and MurNAc, was formed (Fig. 4A). We identified the disaccharide as GlcNAc-MurNAc, through the degradation with the exo- $\beta-N$-acetylglucosaminidase BsNagZ, yielding GlcNAc and MurNAc (Fig. 4A and 4B). In contrast, when TfNamZ2 was incubated with PGN glycans, 
we observed no release of disaccharides. Only small amounts of MurNAc were released, presumably due to the cleavage of terminal MurNAc residues from the non-reducing ends occasionally occurring in the PGN glycan strands (Figure 4B). Also upon incubation with TfNamZ1 small amounts of MurNAc were detected, which is an agreement with the above function of TfNamZ1 in hydrolyzing nonreducing-end terminal MurNAc residues from pNP-MurNAc and MurNAc-GlcNAc.

Notably, small amounts of GlcNAc were identified in the TfNamZ1-digest of PGN glycans but not with TfNamZ2 (Fig. 4B), which likely results from the release of GlcNAc residues located at the reducing end of the glycan strands by TfNamZ1 (Fig. 4B). In agreement with this assumption, TfNamZ1, but not TfNamZ2, cleaved the trisaccharide GlcNAc-MurNAc-GlcNAc $\left([\mathrm{M}+\mathrm{H}]^{+}=700.277 \mathrm{~m} / \mathrm{z}\right)$, which is present in minor amounts in the S. aureus PGN glycan strands preparation (Fig. S4A). Consistently, the tetrasaccharide MurNAc-GlcNAc-MurNAc-GlcNAc, which is also present in low amounts in this preparation, was cleaved twice by TfNamZ1, releasing MurNAc, GlcNAc-MurNAc and GlcNAc, whereas this substrate was cleaved only once by TfNamZ2, yielding MurNAc and GlcNAc-MurNAcGlcNAc residues (Fig. S4A and S4B, see also Fig. 4).

To better characterize the substrate specificity of the TfNamZ proteins, we generated peptidefree, PGN glycan strands also from B. subtilis, by digestion of whole PGN with the MurNAc-L-Ala amidase CwlC of $B$. subtilis as reported [Müller, 2021 \#18933]. As expected, glycan strands from $B$. subtilis were not substrates for the TfNamZ2 enzyme (Fig. S5). However, with this substrate the unique disaccharide-releasing activity of the exo- $\beta-N$-acetylmuramidase TfNamZ1 was confirmed. The digestion of PGN glycans from $B$. subtilis by TfNamZ1 yielded a product with mass of $[\mathrm{M}+\mathrm{H}]^{+}=497.198$ m/z, corresponding to GlcNAc-MurNAc (Fig. 5A), which in turn could be digested by BsNagZ, yielding GlcNAc and MurNAc, but was not cleaved by BsNamZ (Figs. 5A and 5B). Interestingly, we could also show that TfNamZ1 also generates a further product with the mass $[\mathrm{M}+\mathrm{H}]^{+}=455.188 \mathrm{~m} / \mathrm{z}($ Fig. $5 \mathrm{~A})$. 
This mass corresponds to a disaccharide containing $N$-acetylglucosamine GlcN and MurNAc, likely GlcN-MurNAc, since it was neither cleaved by BsNagZ nor by BsNamZ (Fig.5A). Apparently, TfNamZ1 displays a rather broad specificity with respect to the sugar moiety at the nonreducing end, which may be GlcNAc or GlcN.

We could further show that intact $B$. subtilis PGN sacculi, which contain glycans harbouring peptide stems and crosslinks, are not substrates for TfNamZ1 and TfNamZ2 (Fig. S6). Only small amounts of GlcNAc-MurNAc disaccharides were released from B. subtilis PGN sacculi with TfNamZ1, which presumably derived from small parts of the PGN sacculi that lack peptide stems. No peptidecontaining disaccharides or MurNAc-peptides were identified by LC-MS as potential products of TfNamZ1 or TfNamZ2. It should be noted that the amidase CwlC removes both, cross-linked and noncross-linked peptides from the $B$. subtilis sacculi (Fig. S6). The peptide-free PGN glycan polysaccharide chains are not detectable by LC-MS due to their size, however these are readily hydrolysed by TfNamZ1 and the reaction product, which is mainly GlcNAc-MurNAc (besides GlcN-MurNAc, in the case of applying in PGN preparations from B. subtilis) can be detected as shown above.

\section{DISCUSSION}

This study showed that TfNamZ1 (Tanf_08370) and TfNamZ2 (Tanf_00660) of T. forsythia, two members of family 171 of glycosidases (CAZy GH171; www.cazy.org), are exo-lytic $\beta-N$ acetylmuramidase with distinct substrate specificity and product outcome. They revealed distinct activities when peptide-free PGN glycans were used as substrates. They, hence constitute different subgroups within the family 171 of glycosidases. TfNamZ2, like BsNamZ, only cleaved terminal MurNAc entities from the non-reducing-ends of the PGN glycans, whereas TfNamZ1 primarily released 
GlcNAc-MurNAc and GlcN-MurNAc disaccharides from PGN glycans (Figs. 4 and 6). Although, both enzymes were able to hydrolyze pNP-MurNAc and MurNAc-GlcNAc, only TfNamZ2 showed an activity similar to BsNamZ, the previously characterized prototypic exo- $\beta$ - $N$-acetylmuramidase and founding member of this glycosidase family [Müller, 2021 \#18933]. TfNamZ1 had an about 50\% lower activity compared to TfNamZ2 and BsNamZ, when MurNAc-GlcNAc and pNP-MurNAc were used as substrates. It may be speculated that TfNamZ1 and TfNamZ2 differ in their modes of substrate binding, in that the former allows accommodation of a non-reducing terminal disaccharide (GlcNAcMurNAc/GlcN-MurNAc), whereas the latter enzyme only accommodates a non-reducing terminal MurNAc monosaccharide, possibly with higher affinity which could explain the higher enzymatic activity of TfNamZ2 (and BsNamZ) with MurNAc-glycoside substrates. Further structure-function studies are required to fully appreciate the differences in the substrate preferences within the different NamZ enzymes. The different mode of cleavage of TfNamZ1 was unexpected, since the protein share high overall amino acid sequence identity with the exo- $\beta-N$-acetylmuramidase NamZ from $B$. subtilis (46.8\%), whereas the functionally analogous TfNamZ2 share only 36\% identity (and TfNamZ3 37.4\%). This indicates that predictions of the substrate specificities of NamZs cannot be achieved solely on the basis of the primary structure of the proteins (Fig. S1). Accordingly, BsNamZ displays $43.0 \%$ amino acid sequence identity with BfNamZ1 and 41.2\% with BfNamZ2, however BfNamZ1 clusters with TfNamZ1 in a neighbour-joining tree (Fig. S1), suggesting that they are functionally related. Hence, further studies exploring the structure-function of the TfNamZ glycosidases will clarify differences in their catalytic center and structural determinants for the two modes of exo-lytic activities, as well as elucidate the mechanism of action of this family of glycosidases. Clearly, both TfNamZs require substrates, in which the MurNAc carries a free carboxylic acid at the lactyl group that is not substituted by a peptide stem. In agreement with this, we previously showed that a methyl ester derivative of pNP-MurNAc did not serve 
as a substrate for BsNamZ [Müller, 2021 \#18933]. It is tempting to speculate that this carboxylic acid is crucial for specific binding of MurNAc and possibly directly involved in glycoside cleavage.

We recently proposed a pathway whereby $T$. forsythia salvages exogenous PGN derived from the cohabiting bacteria within the oral microbial community for the provision of the essential growth factor MurNAc [Mayer, 2020 \#18932; Hottmann, 2021 \#19871]. This pathway involves PGN uptake and the concomitant removal of its stem peptides by a so far unidentified MurNAc-L-Ala amidase. The removal of the stem peptides of the exogenous PGN may be used by T. forsythia as a mechanism to discriminate its own PGN and thus protects it from enzymatic degradation [Hottmann, 2021 \#19871]. Peptide-free PGN glycan strands are then processed within the periplasm of $T$. forsythia and subsequently MurNAc and PGN-derived disaccharides are internalized via the inner membrane transporters TfMurT and TfAmpG, respectively [Hottmann, 2021 \#19871]. The unique activity of TfNamZ1 fits perfectly with its proposed function in $T$. forsythia. The TfnamZl gene is located upstream of the TfampG gene, coding for the inner membrane transporter TfAmpG, which we have recently shown to import exogenous PGNderived GlcNAc-MurNAc and GlcNAc-anhydro- $N$-acetylmuramic acid (anhMurNAc) [Mayer, 2020 \#18932]. Thus, the products of TfNamZ1 digestion, disaccharide GlcNAc-MurNAc, can be taken up by the inner membrane transporter TfAmpG, whereas MurNAc, the product of TfNamZ2 (and to some extent also of TfNamZ1), is taken up by TfMurT [Ruscitto, 2016 \#14240].

Although we do not have a direct proof that the TfNamZ enzymes function within the periplasm, the N-terminal amino acid sequences of all three proteins contain a putative signal peptide sequence (Sec translocase/signal peptidase I (Sec/SPI) signal sequences) which was confidently identified using the prediction program SignalP-5.0 [Almagro Armenteros, 2019 \#15857]. First attempts to purify the three TfNamZs as full length C-terminally His6 tagged recombinant proteins in a soluble form failed, presumably because the signal peptides interfered with the expression in E. coli as soluble cytoplasmic 
proteins. However, when we removed the predicted signal peptides, two of the recombinant proteins, TfNamZ1 and TfNamZ2, were obtained in a soluble form in high yield. Interestingly, the predicted cleavage sites for the signal peptides of the TfNamZs are located between an alanine (A) and a glutamine (Q) (see also Fig. S1: $\mathrm{A}_{21} \mathrm{Q}_{22}$ for TfNamZ1 and $\mathrm{A}_{24} \mathrm{Q}_{25}$ for TfNamZ2 and TfNamZ3). The AQ signal peptide cleavage sites predicted for all three TfNamZs (as well as for BfNamZ2) follow the so-called Qrule, which likely constitutes a characteristic signal peptide cleavage site among Bacteroidetes species. Concomitant to signal peptide cleavage, the glutamine residue adjacent to the signal peptide anchored at the inner membrane may get cyclized to a pyroglutamate and released into the periplasm [Bochtler, 2018 \#19861].

For TfNamZ3 (Tanf_00855), we failed to obtain a pure soluble protein for so far unknown reasons. This was unexpected, since TfNamZ2 was perfectly soluble and it shares $95 \%$ overall identity and a nearly identical signal-peptide with TfNamZ3 (Fig. S2). Thus, further efforts are required to obtain TfNamZ3 in a soluble form for characterization.

In summary, this study revealed that members of the glycosidase family 171 can have distinct substrate specificity and activity. They either solely release terminal MurNAc residues from the nonreducing ends of substrates, or they possess a somehow broader specificity and can cleave terminal GlcNAc-MurNAc and GlcN-MurNAc disaccharides from the non-reducing ends. Both activities are present in two members of GH171 from $T$. forsythia and may allow this oral pathogen, which is unable to de novo synthesize the MurNAc content of its own PGN, to acquire MurNAc and disaccharides containing MurNAc from surrounding bacteria within its oral habitat. 


\section{MATERIALS AND METHODS}

Chemicals, enzymes, and oligonucleotides. Enzymes for DNA cleavage and cloning were purchased from New England Biolabs (Ipswich, MA) or Fisher Scientific (Schwerte, Germany). The Gene JET plasmid miniprep kit, PCR purification kit, Gene Ruler 1-kb marker and isopropyl $\beta$-Dthiogalactopyranoside (IPTG) were obtained from Fisher Scientific. 2-Acetamido-4-O-(2-acetamido-2deoxy- $\beta$-D-glucopyranosyl)-2-deoxy-D-muramic acid (GlcNAc- MurNAc) and 4-nitrophenyl $N$-acetyl$\beta$-D-glucosaminide (pNP-GlcNAc) were obtained from Carbosynth/Biozol Diagnostica (Eching, Germany). pNP-MurNAc was synthesized as previously described [Müller, 2021 \#18933]. Lysogeny broth (LB Lennox) medium, kanamycin sulfate and acetonitrile (ROTISOLV ${ }^{\circledR}$ HPLC ultra gradient grade) were obtained from Carl Roth GmbH (Karlsruhe, Germany). Oligonucleotide primers, which are listed in Table S1, were purchased from MWG Eurofins (Ebersberg, Germany) or Sigma-Aldrich (St. Louis, USA). Formic acid and ammonium formate for LC-MS analysis were purchased from SigmaAldrich and Merck (Darmstadt, Germany), respectively.

Bacterial strains, plasmids, and growth conditions. The bacterial strains and plasmids used in this study are presented in Table S2. Escherichia coli DH5 $\alpha$ and BL21(DE3) cells were grown in LB Lennox medium under continuous $150 \mathrm{rpm}$ shaking at $37{ }^{\circ} \mathrm{C}$. The LB medium was solidified with $1.5 \%(\mathrm{w} / \mathrm{v})$ agar, if required. E. coli cells containing pET29b or pET28a derived plasmids were cultured in LB medium supplemented with kanamycin $(50 \mu \mathrm{g} / \mathrm{ml})$ and pET16b derived plasmids were maintained by adding ampicillin $(100 \mu \mathrm{g} / \mathrm{ml})$. 
Cloning, expression and purification of recombinant proteins. Recombinant BsNagZ, BsNamZ, BsCwlC, SaAtl ${ }^{\mathrm{AM}}$ and SaAtl ${ }^{\mathrm{Glc}}$ enzymes were purified as previously described [Litzinger, 2010 \#12434;Büttner, 2014 \#13793; Walter, 2021 \#16248;Müller, 2021 \#18933]. For the cloning of TfnamZ13 the respective genes were amplified by PCR using primer pairs as listed in Table S1 and genomic DNA from T. forsythia strain ATCC 43037 (NCBI, Reference Sequence: NZ_JUET00000000.1) [Friedrich, 2015 \#15480;Zwickl, 2020 \#19875]. Importantly, the previously deposited genome in NCBI with the GenBank accession number $\underline{\text { CP00319 }}$ [Dewhirst F., Tanner A., Izard J., Brinkac L., Durkin A.S., Hostetler J., Shetty J., Torralba M., Gill S., Nelson K, Submitted (12-DEC-2011) The J. Craig Venter Institute, 9704 Medical Center Dr., Rockville, MD 20850, USA], as well as entries in the Uniprot database (www.uniprot.org) correspond to the T. forsythia strain 9A2A and not to strain ATCC 43037 as annotated (for an explanation, see [Friedrich, 2015 \#15480;Zwickl, 2020 \#19875]). For the overexpression of the TfNamZs, 1 L LB medium supplemented with $50 \mu \mathrm{g} / \mathrm{ml}$ kanamycin was inoculated with overnight cultures of E. coli BL21(DE3) harboring the expression plasmids pET29b-BsnamZ, pET29b-TfnamZ1, pET29b-TfnamZ2 or pET29b-TfnamZ3 to an initial OD600 of 0.05. Cells were grown to $\log$ phase (at OD600 0.5 to 0.7 ) and after cooling the culture medium to RT, expression of the recombinant proteins was induced by addition of IPTG to a final concentration of $1 \mathrm{mM}$. Bacteria were grown under continuous shaking at $18{ }^{\circ} \mathrm{C}$ and harvested $\left(4000 \mathrm{~g}\right.$ for $30 \mathrm{~min}$ at $\left.4{ }^{\circ} \mathrm{C}\right)$ after overnight incubation. Bacterial pellets were resuspended in $20 \mathrm{ml}$ of sodium phosphate buffer A (20 mM Na2 $\mathrm{HPO}_{4}$ x $2 \mathrm{H}_{2} \mathrm{O}, 500 \mathrm{mM} \mathrm{NaCl}$ with a protease inhibitor cocktail (Roche) each and cells were disrupted using a French Press (Sim-Aminco Spectronic Instruments, Inc) three times at 1000 psi. Sodium phosphate buffer A with $\mathrm{pH} 7.5$ was used for purification of the TfNamZ recombinant enzymes. Cell debris and unbroken cells were removed by centrifugation at $14000 \mathrm{rpm}$ for $60 \mathrm{~min}$ at $4{ }^{\circ} \mathrm{C}$. Purification of the Cterminal His6-tagged TfNamZ proteins was performed by $\mathrm{Ni}^{2+}$ affinity chromatography. Therefore, the obtained supernatants were filtered through sterile PVDF filters (pore size $0.22 \mu \mathrm{m}$ ) and loaded on $1 \mathrm{ml}$ 
His-Trap columns (GE Healthcare), pre-equilibrated with ten column volumes of each Millipore water and sodium phosphate buffer A, using a protein purification system (ÄKTApurifier, GE Healthcare). Elution of the proteins was achieved by using a linear gradient of imidazole from $4 \mathrm{mM}$ to $500 \mathrm{mM}$ with sodium phosphate buffer B $\left(20 \mathrm{mM} \mathrm{Na} \mathrm{HPO}_{4} \times 2 \mathrm{H}_{2} \mathrm{O}, 500 \mathrm{mM} \mathrm{NaCl}, 500 \mathrm{mM}\right.$ imidazole, $\left.\mathrm{pH} 7.5\right)$. Purity of the $T$. forsythia enzymes was analyzed by $12 \%$ SDS-PAGE after staining with Coomassie Brilliant Blue G250 dye. Peak fractions containing desired proteins were pooled and further purified by SEC (HiLoad 16/60 Superdex 200 column, GE Healthcare) using sodium phosphate buffer A with pH 7.5 as eluent. Peak fractions were analyzed for pure proteins by $12 \%$ SDS-PAGE and fractions containing pure enzymes were pooled and concentrated using Vivaspin concentrators with $30 \mathrm{kDa}$ cut-off filter (Sartorius). Protein concentrations were determined using the corresponding extinction coefficient at $280 \mathrm{~nm}$ (ExPASy, ProtParam tool) and measured in a $1 \mathrm{ml}$ quartz cuvette (Hellma Analytics) using a SpectraMax M2 spectrophotometer (Molecular Devices). Proteins were long-term stored at $-80{ }^{\circ} \mathrm{C}$ in $10 \%$ glycerol.

\section{PGN isolation from $B$. subtilis 168 and $S$. aureus USA300 JE2}

For the isolation of PGN from B. subtilis strain 168, 1 L LB medium was inoculated with an overnight culture to an initial OD600 of 0.1. Cells were grown aerobically to an OD600 of 1, centrifuged down and resuspended in $15 \mathrm{ml}$ of Tris buffer $(100 \mathrm{mM}, \mathrm{pH} 8)$ supplemented with $400 \mu \mathrm{g}$ of proteinase $\mathrm{K}$ to prevent self-hydrolysis of PGN by endogenous autolytic enzymes. Afterwards, the bacteria were added dropwise to an equal amount of boiling Tris buffer and boiling was continued under constant stirring for $1 \mathrm{hr}$. The cell pellet was centrifuged $(4,000 \times \mathrm{g})$ for $15 \mathrm{~min}$ and the pellet was stored at $4{ }^{\circ} \mathrm{C}$. Frozen bacterial cells were resuspended in $6 \mathrm{ml}$ of Tris buffer, containing $600 \mu \mathrm{g}$ of $\alpha$-amylase, $100 \mu \mathrm{g}$ of RNase A and $50 \mathrm{U}$ of DNase I and incubated for $2 \mathrm{hrs}$ at $37^{\circ} \mathrm{C}$ under constant shaking. Afterwards, proteinase $\mathrm{K}$ (400 $\left.\mu \mathrm{g}\right)$ 
was added and the mixture was boiled for $1 \mathrm{hr}$ in an equal volume of SDS (final concentration of $2 \%$ ). The crude PGN sample was subsequently transferred to $15 \mathrm{ml}$ conical tubes (3148-0050, Thermo Scientific) and sacculi were spun down at 22,000 x g at $40{ }^{\circ} \mathrm{C}$ for $30 \mathrm{~min}$ in a Heraeus Multifuge X1R using a Fiberlite ${ }^{\mathrm{TM}}$ F15-8 x 50cy Fixed Angle Rotor from Thermo Scientific. SDS was removed by washing the sacculi with $60^{\circ} \mathrm{C}$ pre-warmed Millipore water several times until no SDS was detected by the methylene blue assay [Hayashi, 1975 \#12401]. The wall teichoic acids, which are covalently bound to the MurNAc-moiety of the PGN, were further removed by incubation of the B. subtilis sacculi in $5 \mathrm{ml}$ of $1 \mathrm{M} \mathrm{HCl}$ at $37{ }^{\circ} \mathrm{C}$ for $4 \mathrm{hrs}$ under constant rotation. Afterwards, the PGN sacculi were centrifuged in a table centrifuge (max. speed for $10 \mathrm{~min}$ ) and the pellet was washed with Millipore water until $\mathrm{pH}>6$ with $\mathrm{pH}$ indicator strips was reached. The pellet was then dried under vacuum at $40{ }^{\circ} \mathrm{C}$ and pellets were stored at $4^{\circ} \mathrm{C}$.

For the isolation of PGN from S. aureus strain USA300 JE2, a previously described protocol [Turner, 2016 \#14928] with modifications was applied. Briefly, overnight culture of S. aureus was inoculated in $1 \mathrm{~L} \mathrm{LB}$ medium to an initial $\mathrm{OD}_{600}$ of 0.05 . Cells were grown for about $20 \mathrm{~h}$ aerobically to a $\mathrm{OD}_{600}$ of 6.1, centrifuged and pellets were frozen at $-80{ }^{\circ} \mathrm{C}$. Furthermore, the bacteria were placed on ice, resuspended in $60 \mathrm{ml}$ ice-cold Millipore water and added dropwise to $60 \mathrm{ml}$ pre-boiled 10\% SDS (final concentration of 5\%). After $1 \mathrm{hr}$ of constant boiling under stirring, SDS was removed from the sacculi by several washing steps with pre-warmed $60{ }^{\circ} \mathrm{C}$ Millipore water until no SDS was detected [Hayashi, $1975 \# 12401]$. The bacterial pellet was resuspended in $12 \mathrm{ml}$ Millipore water and cells were added to glass beads ( $0.1 \mathrm{~mm}$ from Roth) in $15 \mathrm{ml}$ tubes (Precellys). Cells were broken in Precellys Evolution cell disrupter (speed 6.5, four times each for $40 \mathrm{~s}$ ) and the glass beads were separated from the sacculi by using a $40 \mu \mathrm{m}$ nylon mesh cell strainer (Fisher Scientific). Obtained S. aureus sacculi were collected in $40 \mathrm{ml}$ Millipore water, centrifuged at high speed and redissolved in $20 \mathrm{ml}$ of Tris- $\mathrm{HCl}$ (50 mM, pH 7.6) with $10 \mathrm{mM} \mathrm{MgCl} 2$ and $1200 \mathrm{U}$ DNase I and $1000 \mu \mathrm{g}$ RNase A. Digestions were performed at $37^{\circ} \mathrm{C}$ for 
$3 \mathrm{hrs}$ under constant rotation, sacculi were centrifuged and redissolved in $20 \mathrm{ml}$ of Tris- $\mathrm{HCl}$ buffer (50 mM, pH 7.6) with 2 mg Trypsin (Sigma-Aldrich, T-4799). Trypsin digestion was performed overnight at $37{ }^{\circ} \mathrm{C}$ under constant shaking. To remove the wall teichoic acid, sacculi were resuspended in $10 \mathrm{ml}$ of $48 \%$ hydrofluoric acid for $48 \mathrm{hrs}$ at $4{ }^{\circ} \mathrm{C}$ under constant shaking. $S$. aureus sacculi were transferred to Eppendorf tubes, centrifuged in a table centrifuge (13000 rpm for $7 \mathrm{~min}$ ) and the PGN pellets were washed several times with Millipore water until $\mathrm{pH}$ of about 6.5 with $\mathrm{pH}$ indicator strips was reached. PGN was dried in a vacuum concentrator and pellets were stored at $4{ }^{\circ} \mathrm{C}$.

\section{Specificity of TfNamZs to chromogenic pNP substrates}

$150 \mu \mathrm{M}$ of the chromogenic substrates pNP-GlcNAc or pNP-MurNAc were incubated with $2 \mu \mathrm{M}$ of BsNagZ, BsNamZ or TfNamZs enzymes at $37{ }^{\circ} \mathrm{C}$ in $50 \mathrm{mM}$ phosphate buffer for pNP-GlcNAc (pH 7) and for pNP-MurNAc ( $\mathrm{pH} 8$ ). Enzymatic reactions with the chromogenic substrates were performed in a round bottom 96 well/plate (Greiner Bio-One) in a final volume of $100 \mu 1$. After overnight incubations, reactions were stopped by adding $50 \mu \mathrm{l}$ of $100 \mathrm{mM}$ carbonate buffer $\left(\mathrm{Na}_{2} \mathrm{CO}_{3} / \mathrm{NaHCO}_{3}, \mathrm{pH} 10.8\right)$ and pictures were taken to visualize the development of a yellow colour, obtained by the release of $\mathrm{pNP}$ in the enzymatic reactions.

\section{Specificity of TfNamZs for MurNAc-GIcNAc and GIcNAc-MurNAc}

Substrate specificity of TfNamZs was also tested with commercially available disaccharide GlcNAcMurNAc and the disaccharide MurNAc-GlcNAc, which was prepared by enzymatic digestion of isolated PGN sacculi. Therefore, $0.1 \mathrm{mg}$ PGN from $S$. aureus USA300 (prepared as described above) was digested overnight with $5 \mu \mathrm{g} \mathrm{SaAtl}{ }^{\mathrm{AM}}$ and $5 \mu \mathrm{g} \mathrm{SaAtl}^{\mathrm{Glc}}$ enzymes in a final volume of $50 \mu 1$ in $50 \mathrm{mM}$ 
phosphate buffer, $\mathrm{pH} 7.5$. The sample was boiled for $10 \mathrm{~min}$ at $95^{\circ} \mathrm{C}$ and after centrifugation $(13,000$ $\mathrm{rpm} ; 10 \mathrm{~min})$, the supernatant was further digested with the exo- $N$-acetylglucosaminidase BsNagZ (2.5 $\mu \mathrm{M}$ ) for 3 hrs (final volume of $50 \mu \mathrm{l}$ ) to cleave the GlcNAc-MurNAc-GlcNAc content of the MurNAcGlcNAc sample, that was obtained during the digestion of the PGN glycans with the SaAtl ${ }^{\text {Glc }}$. After boiling the samples, no enzyme (buffer) or recombinant BsNamZ, TfNamZ1 or TfNamZ2 (each $2.5 \mu \mathrm{M}$ ) enzymes were added to the enzyme reaction and samples were incubated overnight in final volume of 50 $\mu 1$. Finally, samples were boiled, centrifuged at maximum speed on the table centrifuge and supernatants were stored at $4{ }^{\circ} \mathrm{C}$.

In addition, GlcNAc-MurNAc $(0.5 \mathrm{mM})$ was incubated with either of the recombinant NamZ enzymes from $T$. forsythia or from BsNagZ $(2.5 \mu \mathrm{M}$ each) in phosphate buffer, $\mathrm{pH} 7$ in a final volume of $50 \mu 1$. Overnight reactions were stopped by heating the samples at $95{ }^{\circ} \mathrm{C}$ for 10 minutes. Samples were then centrifuged $(13,000 \mathrm{rpm} ; 10 \mathrm{~min})$ and the supernatants were kept at $4{ }^{\circ} \mathrm{C}$.

Supernatants were analyzed by LC-MS for the presence of MurNAc-GlcNAc, MurNAc and GlcNAc. The exact monoisotopic masses $[\mathrm{M}]$ of the proton adduct $[\mathrm{M}+\mathrm{H}]^{+}$of the investigated peptidoglycan sugar metabolites MurNAc-GlcNAc, MurNAc and GlcNAc are summarized in Table S3. The relative metabolite concentrations ( $\%$ area under the curve, AUC) represent the mean from three biological replicates. The areas under the curve of the respective extracted ion chromatograms were calculated and are presented in $\%$.

\section{Specificity of TfNamZs for PGN and PGN-derived glycan substrates}

PGN from B. subtilis $(0.5 \mathrm{mg})$ was resuspended in phosphate buffer $(\mathrm{pH} 7.0,50 \mathrm{mM})$ and incubated with $2.5 \mu \mathrm{M}$ TfNamZ1 or TfNamZ2. The reaction was incubated at $37{ }^{\circ} \mathrm{C}$ overnight under constant rotation 
and stopped at $95{ }^{\circ} \mathrm{C}$ for 10 minutes. The samples were then centrifuged and the supernatants were analyzed by MS.

To generate peptide-free PGN glycan strands from B. subtilis, 2 mg PGN was solved in $200 \mu 1$ Tris- $\mathrm{HCl}$ buffer (pH 8, $100 \mathrm{mM}$ ) and $5 \mu \mathrm{g}$ of the MurNAc-L-Ala amidase CwlC from B. subtilis (BsCwlC) was added to the murein sacculi. Peptides were digested at $60^{\circ} \mathrm{C}$ for $6 \mathrm{hrs}$, and enzyme reactions were stopped by inactivation at $95{ }^{\circ} \mathrm{C}$ for $10 \mathrm{~min} .1 / 4$ of the CwlC-digested PGN was dried and then solved in a phosphate buffer (pH 7, $100 \mathrm{mM}$ ) and incubated overnight with buffer (control) or with $2.5 \mu \mathrm{M}$ TfNamZ1 or TfNamZ2 enzymes in a final volume of $50 \mu 1$. Samples were heat inactivated and the supernatants were analyzed by HPLC-MS.

For the generation of PGN peptide-free glycan strands from S. aureus, $0.1 \mathrm{mg}$ of the purified sacculi were incubated with $5 \mu \mathrm{g}$ of SaAtl ${ }^{\mathrm{AM}}$ recombinant enzyme in phosphate buffer ( $\left.\mathrm{pH} 7.5\right)$ in a final volume of $40 \mu$ l. Sample was incubated at $37^{\circ} \mathrm{C}$ under constant rotation. After overnight incubation, enzymes were inactivated by heating, samples were centrifuged and $2.5 \mathrm{mM}$ of the TfNamZ or BsNamZ enzymes were added to the supernatants (final volume of $40 \mu 1$ ). After overnight incubation, enzymes were inactivated by heating, centrifuged and the supernatant was analyzed by HPLC-MS.

\section{LC-MS analysis of disaccharides or PGN-derived substrates}

$5 \mu 1$ samples were subjected to LC-MS analysis using an UltiMate 3000 LC system (Dionex) coupled to an electrospray-ionization-time of flight mass spectrometer (MicrO-TOF II; Bruker) that was operated in positive-ion mode. Metabolite separation was performed with a Gemini $\mathrm{C}_{18}$ column $(150$ x $4.6 \mathrm{~mm}$, $110 \AA$, $5 \mu \mathrm{m}$; Phenomenex) at $37^{\circ} \mathrm{C}$ with a flow rate of $0.2 \mathrm{ml} / \mathrm{min}$ using a 45 -min gradient program as described in [Gisin, 2013] with optimized column re-equilibration step: 5 min, 100\% buffer A $(0.1 \%$ 
formic acid with $0.05 \%$ ammonium formate in Millipore water), then $30 \mathrm{~min}$ of a linear gradient to $40 \%$ buffer B (acetonitrile), and 10 min of $100 \%$ buffer A for column re-equilibration. The mass spectra of the samples were analysed with Data Analysis (Bruker) and Prism 8 (GraphPad) software and are shown as base peak chromatograms (BPCs) and extracted ion chromatograms (EICs) of metabolites presented as measured $\mathrm{m} / \mathrm{z}$ values. Theoretical $\mathrm{m} / \mathrm{z}$ values of the investigated sugar metabolites are summarized in Table S3.

\section{ACKNOWLEDGMENTS}

We thank Prof. Thilo Stehle for providing us with the Atl ${ }^{\mathrm{AM}}$ enzyme, Maraike Müller and Isabel Hottmann help in the initial phase of the project and Axel Walter for bioinformatic support. Dirk Hauck (HIPS) is acknowledged for excellent technical support.

\section{SUPPORTING INFORMATION}

This article contains supporting information.

\section{AUTHOR CONTRIBUTIONS}

$\mathrm{KB}$ and $\mathrm{MB}$ conducted experiments, $\mathrm{MB}$ and $\mathrm{CM}$ wrote and designed the manuscript, AL and AT conceived ideas and AT provided pNP-MurNAc. All authors read and approved the final version of the manuscript. 


\section{FUNDING INFORMATION}

This work was supported by the Deutsche Forschungsgemeinschaft (DFG) - Project-IDs 314202130

(DACh programme) and 174858087 (GRK 1708, TP-B2) to CM. Furthermore, infrastructural support from the Cluster of Excellence EXC 2124 Controlling Microbes to Fight Infections, project ID 390838134, and the GRK 1708 Molecular Principles of Bacterial Survival Strategies, project ID 174858087, is kindly acknowledged. AL is currently supported by a Wellcome Trust Investigator Award. We thank Libera Lo Presti for critically reading and editing of the manuscript.

\section{CONFLICT OF INTERESTS}

The authors declare no conflict of interests.

\section{ETHICAL STATEMENT}

Ethics approval was not required, as the work includes only an in vitro characterization of carbohydrate metabolic enzymes.

\section{REFERENCES}

1. Walter A, Mayer C. 2019. Peptidoglycan structure, biosynthesis, and dynamics during bacterial growth, p 237-299. In Cohen E, Merzendorfer H (ed), Extracellular sugar-based biopolymers matrices doi:10.1007/978-3-030-12919-4_6. Springer, Cham. 
2. Ragland SA, Criss AK. 2017. From bacterial killing to immune modulation: Recent insights into the functions of lysozyme. PLoS Pathog 13:e1006512.

3. Oshida T, Sugai M, Komatsuzawa H, Hong YM, Suginaka H, Tomasz A. 1995. A Staphylococcus aureus autolysin that has an $\mathrm{N}$-acetylmuramoyl-L-alanine amidase domain and an endo- $\beta-N$ acetylglucosaminidase domain: cloning, sequence analysis, and characterization. Proc Natl Acad Sci U S A 92:285-289.

4. Mayer C. 2012. Bacterial cell wall recycling. John Wiley \& Sons Ltd, Chichester.

5. Dik DA, Marous DR, Fisher JF, Mobashery S. 2017. Lytic transglycosylases: concinnity in concision of the bacterial cell wall. Crit Rev Biochem Mol Biol 52:503-542.

6. Litzinger S, Duckworth A, Nitzsche K, Risinger C, Wittmann V, Mayer C. 2010. Muropeptide rescue in Bacillus subtilis involves sequential hydrolysis by $\beta$ - $N$-acetylglucosaminidase and $N$ acetylmuramyl-L-alanine amidase. J Bacteriol 192:3132-3143.

7. Müller M, Calvert M, Hottmann I, Kluj RM, Teufel T, Balbuchta K, Engelbrecht A, Selim KA, Xu

Q, Borisova M, Titz A, Mayer C. 2021. The exo- $\beta-N$-acetylmuramidase NamZ from Bacillus subtilis is the founding member of a family of exo-lytic peptidoglycan hexosaminidases. J Biol Chem 296:100519.

8. Borisova M, Gaupp R, Duckworth A, Schneider A, Dalugge D, Mühleck M, Deubel D, Unsleber S, Yu W, Muth G, Bischoff M, Götz F, Mayer C. 2016. Peptidoglycan recycling in Gram-positive bacteria is crucial for survival in stationary phase. mBio 7:e00923-00916.

9. Loyola-Rodriguez JP, Martinez-Martinez RE, Abud-Mendoza C, Patino-Marin N, Seymour GJ. 2010. Rheumatoid arthritis and the role of oral bacteria. J Oral Microbiol 2.

10. Martinez-Rivera JI, Xibille-Friedmann DX, Gonzalez-Christen J, de la Garza-Ramos MA, CarrilloVazquez SM, Montiel-Hernandez JL. 2017. Salivary ammonia levels and Tannerella forsythia are associated with rheumatoid arthritis: A cross sectional study. Clin Exp Dent Res 3:107-114.

11. Bourgeois D, Inquimbert C, Ottolenghi L, Carrouel F. 2019. Periodontal pathogens as risk factors of cardiovascular diseases, diabetes, rheumatoid arthritis, cancer, and chronic obstructive pulmonary disease - is there cause for consideration? Microorganisms 7. 
12. Hottmann I, Borisova M, Schäffer C, Mayer C. 2021. Peptidoglycan salvage enables the periodontal pathogen Tannerella forsythia to survive within the oral microbial community. Microb Physiol 31:123-134.

13. Wyss C. 1989. Dependence of proliferation of Bacteroides forsythus on exogenous $N$ acetylmuramic acid. Infect Immun 57:1757-1759.

14. Mayer VMT, Hottmann I, Figl R, Altmann F, Mayer C, Schäffer C. 2019. Peptidoglycan-type analysis of the $\mathrm{N}$-acetylmuramic acid auxotrophic oral pathogen Tannerella forsythia and reclassification of the peptidoglycan-type of Porphyromonas gingivalis. BMC Microbiol 19:200.

15. Hottmann I, Mayer VMT, Tomek MB, Friedrich V, Calvert MB, Titz A, Schäffer C, Mayer C. 2018. N-Acetylmuramic acid (MurNAc) auxotrophy of the oral pathogen Tannerella forsythia: characterization of a MurNAc kinase and analysis of Its role in cell wall metabolism. Front Microbiol 9:19.

16. Ruscitto A, Hottmann I, Stafford GP, Schäffer C, Mayer C, Sharma A. 2016. Identification of a novel $\mathrm{N}$-acetylmuramic acid transporter in Tannerella forsythia. J Bacteriol 198:3119-3125.

17. Ruscitto A, Sharma A. 2018. Peptidoglycan synthesis in Tannerella forsythia: scavenging is the modus operandi. Mol Oral Microbiol 33:125-132.

18. Mayer VMT, Tomek MB, Figl R, Borisova M, Hottmann I, Blaukopf M, Altmann F, Mayer C, Schäffer C. 2020. Utilization of different MurNAc sources by the oral pathogen Tannerella forsythia and role of the inner membrane transporter AmpG. BMC Microbiol 20:352.

19. Ruscitto A, Honma K, Veeramachineni VM, Nishikawa K, Stafford GP, Sharma A. 2017. Regulation and molecular basis of environmental muropeptide uptake and utilization in fastidious oral anaerobe Tannerella forsythia. Front Microbiol 8:648.

20. Litzinger S, Fischer S, Polzer P, Diederichs K, Welte W, Mayer C. 2010. Structural and kinetic analysis of Bacillus subtilis $\mathrm{N}$-acetylglucosaminidase reveals a unique Asp-His dyad mechanism. J Biol Chem 285:35675-33584. 
21. Nega M, Tribelli PM, Hipp K, Stahl M, Götz F. 2020. New insights in the coordinated amidase and glucosaminidase activity of the major autolysin (Atl) in Staphylococcus aureus. Communications Biology 3.

22. Almagro Armenteros JJ, Tsirigos KD, Sonderby CK, Petersen TN, Winther O, Brunak S, von Heijne G, Nielsen H. 2019. SignalP 5.0 improves signal peptide predictions using deep neural networks. Nat Biotechnol 37:420-423.

23. Bochtler M, Mizgalska D, Veillard F, Nowak ML, Houston J, Veith P, Reynolds EC, Potempa J. 2018. The Bacteroidetes Q-rule: pyroglutamate in signal peptidase I substrates. Front Microbiol 9:230.

24. Büttner FM, Zoll S, Nega M, Götz F, Stehle T. 2014. Structure-function analysis of Staphylococcus aureus amidase reveals the determinants of peptidoglycan recognition and cleavage. J Biol Chem 289:11083-11094.

25. Walter A, Friz S, Mayer C. 2021. Chitin, chitin oligosaccharide, and chitin disaccharide metabolism of Escherichia coli revisited: reassignment of the roles of ChiA, ChbR, ChbF, and ChbG. Microb Physiol 31:178-194.

26. Friedrich V, Pabinger S, Chen T, Messner P, Dewhirst FE, Schäffer C. 2015. Draft genome sequence of Tannerella forsythia type strain ATCC 43037. Genome Announc 3.

27. Zwickl NF, Stralis-Pavese N, Schäffer C, Dohm JC, Himmelbauer H. 2020. Comparative genome characterization of the periodontal pathogen Tannerella forsythia. BMC Genomics 21:150.

28. Hayashi K. 1975. A rapid determination of sodium dodecyl sulfate with methylene blue. Anal Biochem 67:503-506.

29. Turner RD, Hobbs JK, Foster SJ. 2016. Atomic force microscopy analysis of bacterial cell wall peptidoglycan architecture. Methods Mol Biol 1440:3-9.

30. Gisin J, Schneider A, Nägele B, Borisova M, Mayer C. 2013. A cell wall recycling shortcut that bypasses peptidoglycan de novo biosynthesis. Nat Chem Biol 9:491-493.

31. Kanehisa M, Goto S. 2000. KEGG: kyoto encyclopedia of genes and genomes. Nucleic Acids Res 28:27-30. 


\section{Figure legends:}

B. subtilis

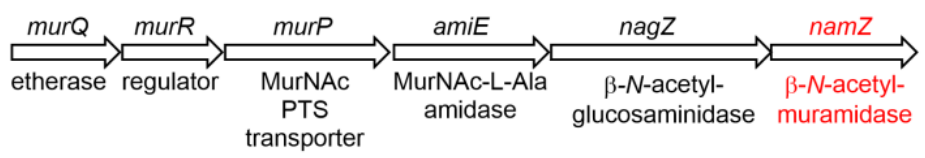

T. forsythia

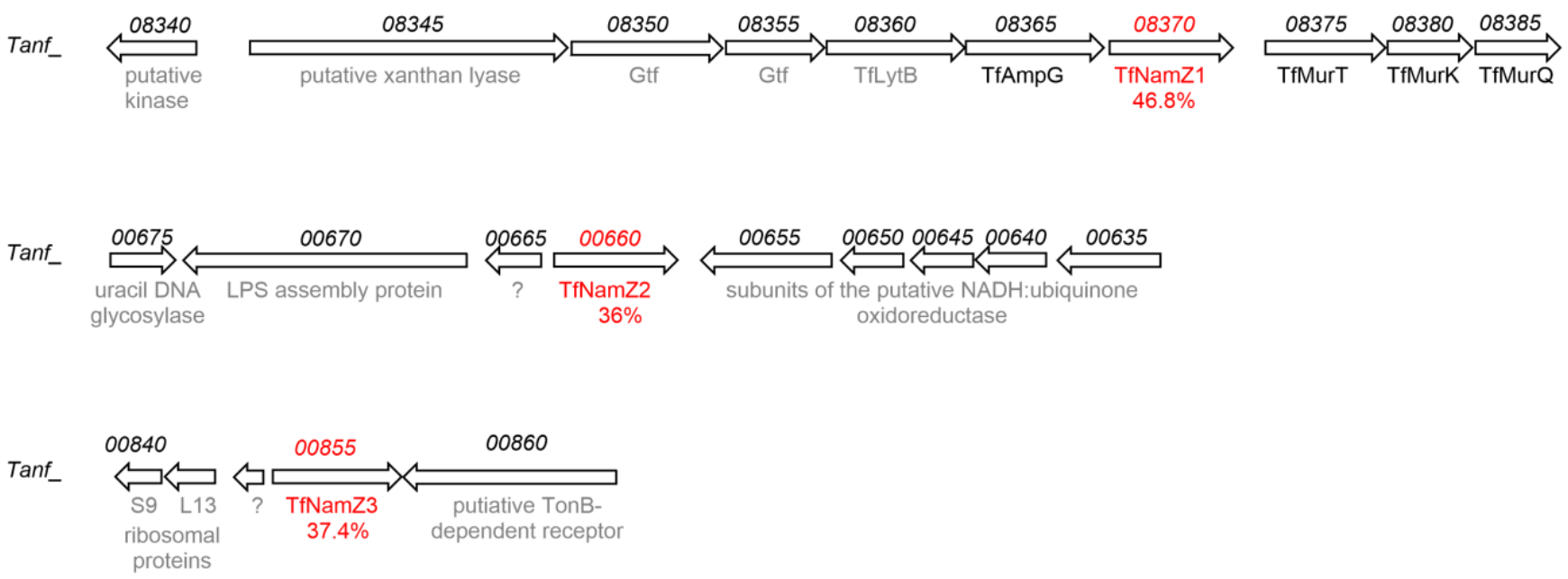

FIG. 1. Genomic organization of the exo- $N$-acetylmuramidase nam $Z$ of $B$. subtilis and the three putative namZ-like genes of $\boldsymbol{T}$. forsythia. The namZ operon of B. subtilis strain 168 (NCBI Reference Sequence accession no. NC_000964.3) includes three genes (amiE, nagZ and namZ) involved in PGN turnover/recycling and three genes (murQRP) required for the uptake of MurNAc and the transcriptional regulation of the operon: amiE encodes the exo-MurNAc-L-Ala amidase BsAmiE [Litzinger, 2010 $\# 12434$ ], nagZ encodes the exo- $\beta-N$-acetylglucosaminidase BsNagZ [Litzinger, 2010 \#12680] and namZ encodes the recently identified and characterized exo- $\beta-N$-acetylglucosaminidase BsNamZ (in red) [Müller, 2021 \#18933]; furthermore, murP encodes the MurNAc-specific phosphotransferase system (PTS) transporter BsMurP, murQ encodes the MurNAc 6-phosphate etherase MurQ and murR encodes 
the putative transcriptional regulator of the operon [Borisova, $2016 \# 14239$ ]. Within the genome of $T$. forsythia strain ATCC 43037 (NCBI Reference Sequence: NZ_JUET00000000.1), three orthologous namZ-like family GH171 glycosidases (CAZy GH171; www.cazy.org) were identified, TfnamZ1 (Tanf_08370), TfnamZ2 (Tanf_00660) and TfnamZ3 (Tanf_00855). According to the Kegg Database [Kanehisa, 2000 \#20023], the TfnamZ1 cluster of T. forsythia includes 9 genes (Tanf_08345 to Tanf_08385), with Tanf_08375, Tanf_08380 and Tanf_08385, encoding the MurNAc transporter TfMurT [Ruscitto, $2016 \# 14240$ ], the MurNAc kinase TfMurK [Hottmann, 2018 \#14525], and the MurNAc 6-phosphate etherase TfMurQ [Ruscitto, 2016 \#14240], respectively, which are involved in MurNAc transport and catabolism. The genes upstream of TfnamZ1 (Tanf_08370) encode the inner membrane permease TfAmpG (Tanf_08365), which was recently shown to transport the disaccharides GlcNAc-MurNAc and GlcNAc-anhMurNAc [Mayer, 2020 \#18932] and a putative lytic transglycosylase, which we named TfLytB (Tanf_08360). The functions of the further upstream genes are unknown: Tanf_08350 and Tanf_08355 encode two putative glycosyltransferases (Gtf), and Tanf_08345 a putative xanthan lyase. The gene TfnamZ2 (Tanf_00660) is organized in a gene cluster with three other genes, Tanf_00675, Tanf_00670 and Tanf_00665, which encode an uracil DNA glycosylase, LPS assembly protein and a hypothetical protein, respectively. The third namZ ortholog of T. forsythia, TfnamZ3 (Tanf_00855) is a monocistronic gene. Genes that code for proteins of a yet uncharacterized function, indicated by a question mark, are presented in gray, characterized proteins are shown in black, and the nam $Z$ genes are shown in red. 


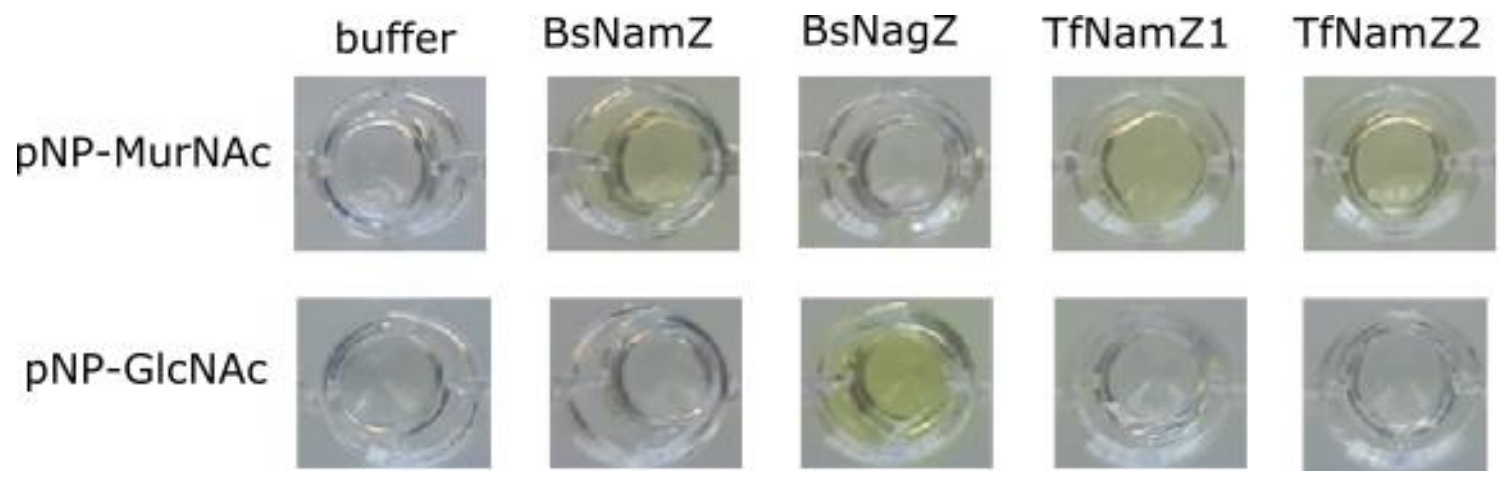

FIG. 2. Specificity of NamZ proteins for the chromogenic substrates pNP-GlcNAc and pNPMurNAc. The recombinant enzymes TfNamZ1 and TfNamZ2 were assayed, together with two recombinant enzymes from $B$. subtilis 168 of known activity. The $\beta$ - $N$-acetylmuramidase BsNamZ cleaves pNP-MurNAc and the $\beta$ - $N$-acetylglucosaminidase BsNagZ cleaves pNP-GlcNAc, as evidenced by the development of a yellow colour upon the release of para-nitrophenol. TfNamZ1 and TfNamZ2, both showed exo- $\beta$ - $N$-acetylmuramidase activity, i.e., they specifically cleaved pNP-MurNAc, and showed no $\beta$ - $N$-acetylglucosaminidase activity, i.e. no cleavage of pNP-GlcNAc. 


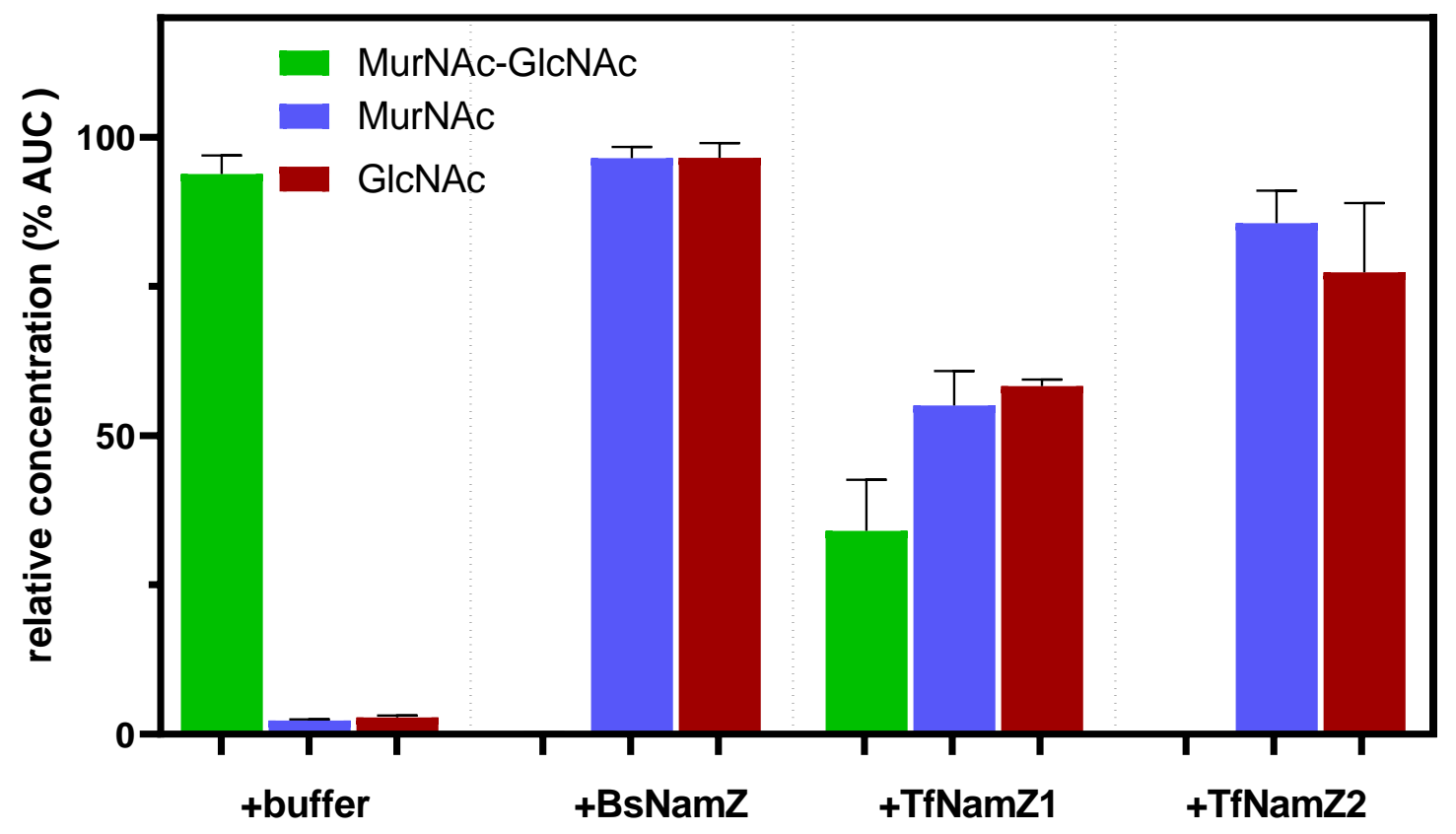

FIG. 3. Cleavage of MurNAc-GIcNAc by BsNamZ, TfNamZ1 and TfNamZ2. MurNAc-GlcNAc, generated by digestion of $S$. aureus peptidoglycan (PGN) with SaAtl ${ }^{\mathrm{AM}}, \mathrm{SaAtl}{ }^{\mathrm{Glc}}$ and BsNagZ was incubated for $20 \mathrm{~h}$ at $37^{\circ} \mathrm{C}$ with the BsNamZ, TfNamZ1, TfNamZ2 or buffer (as control). The remaining substrate (MurNAc-GlcNAc, green) in the reaction mixture and the reaction products (MurNAc, blue; GlcNAc, red) were quantified using LC-MS. The relative metabolite concentrations ( $\%$ area under the curve, AUC, of the respective mass peak) represent the mean from three biological replicates. 

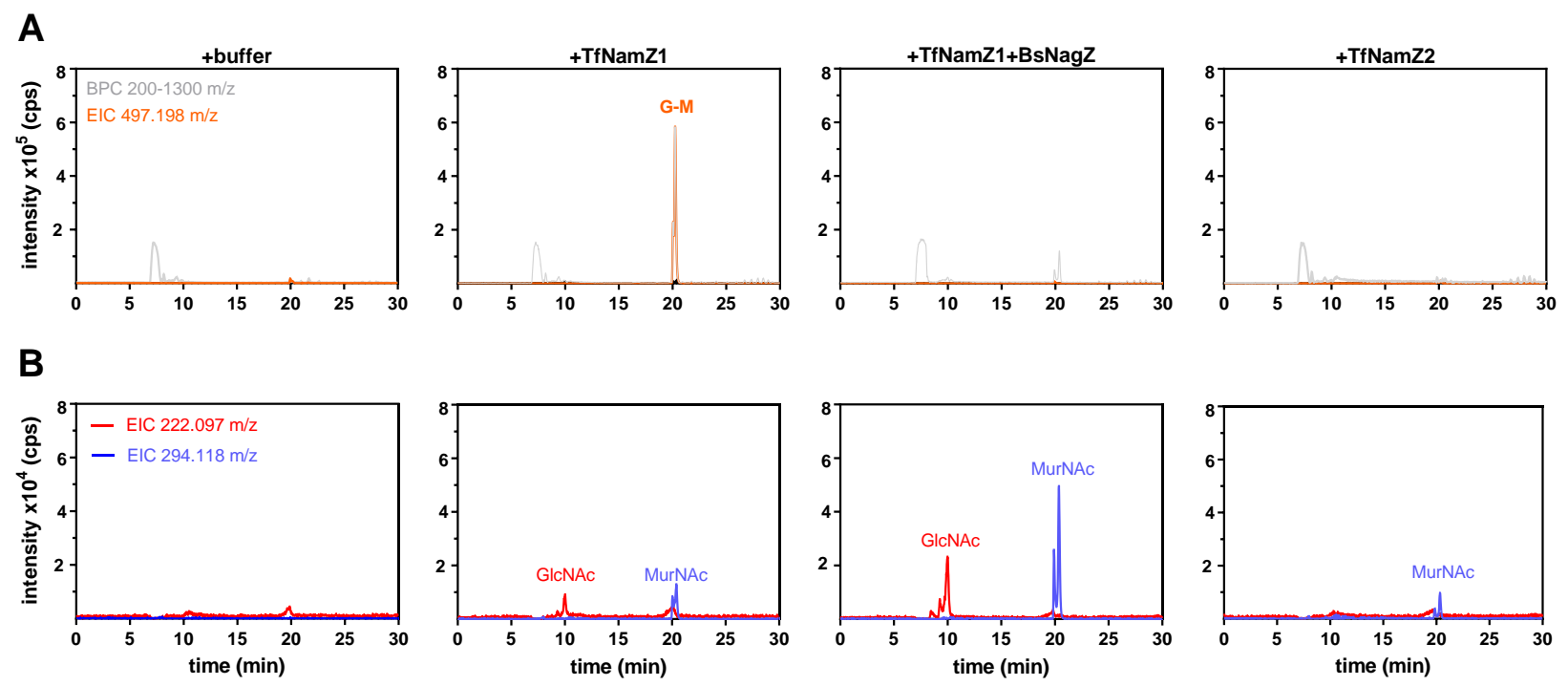

FIG. 4. TfNamZ1 and TfNamZ2 show differences in product formation when incubated with PGN-

derived glycans from S. aureus. Peptide-free PGN glycans were generated by digestion of PGN sacculi isolated from S. aureus strain USA300 with the S. aureus amidase SaAtl ${ }^{\mathrm{AM}}$. The PGN glycan strands were incubated for $20 \mathrm{hrs}$ at $37{ }^{\circ} \mathrm{C}$ with TfNamZ1 or TfNamZ2 recombinant enzymes, or buffer as a control (as indicated). Subsequently, the TfNamZ1 digested glycan strands were further digested with BsNagZ (TfNamZ1+BsNagZ). The metabolite concentrations (peak intensities; cps) in the reaction mixtures were analyzed by LC-MS. A. Base peak chromatograms (gray lines) and extracted ion chromatograms (EIC) corresponding to GlcNAc-MurNAc (orange), with $[\mathrm{M}+\mathrm{H}]^{+}=497.198 \mathrm{~m} / \mathrm{z}$ are presented. B. EICs, corresponding to GlcNAc (red) and MurNAc (blue), with $[\mathrm{M}+\mathrm{H}]^{+}=222.097 \mathrm{~m} / \mathrm{z}$ and $[\mathrm{M}+\mathrm{H}]^{+}=294.118 \mathrm{~m} / \mathrm{z}$, respectively, were plotted. 

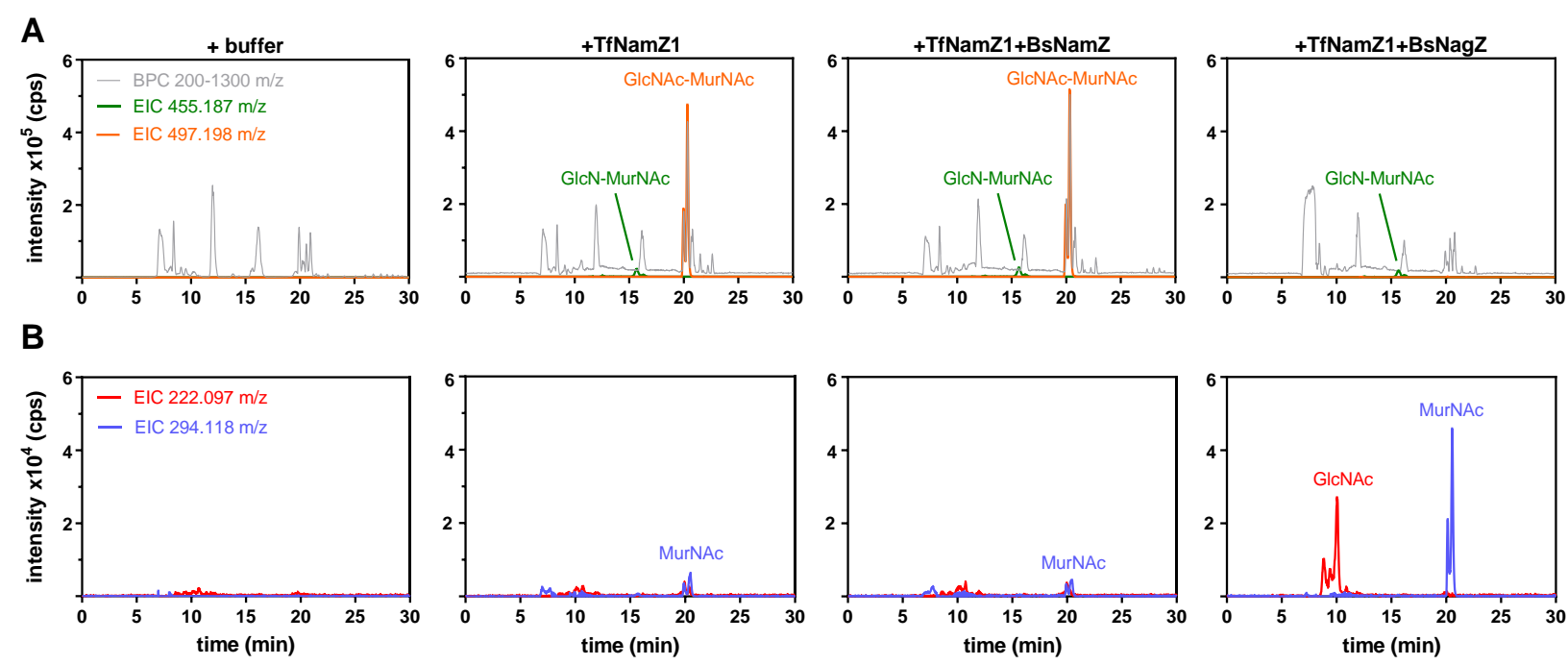

FIG. 5. Substrate specificity of TfNamZ1 with PGN-derived glycans from B. subtilis. PGN glycan

strands from $B$. subtilis were generated by digestion of PGN sacculi isolated from B. subtilis 168 with the $B$. subtilis amidase $\mathrm{BsCwlC}$. The enzyme reactions were heat inactivated and the generated B. subtilis glycan strands were incubated with TfNamZ1 or buffer as a control. Subsequently, the TfNamZ1 digested glycan strands were further digested with BsNamZ (TfNamZ1+BsNamZ) or with BsNagZ (TfNamZ1+BsNagZ). Enzyme reactions were analyzed by LC-MS in positive ion mode. A. Data are presented as base peak chromatograms $200-1300 \mathrm{~m} / \mathrm{z}$ (gray lines) and as extracted ion chromatogram (EIC), corresponding to GlcNAc-MurNAc (orange) and GlcN-MurNAc (green) with $[\mathrm{M}+\mathrm{H}]^{+}=497.198$ $\mathrm{m} / \mathrm{z}$ and or of $[\mathrm{M}+\mathrm{H}]^{+}=455.187 \mathrm{~m} / \mathrm{z}$, respectively, are shown as intensities (cps). B. Data are presented as EICs (intensity; cps), corresponding to GlcNAc (red) and MurNAc (blue), with $[\mathrm{M}+\mathrm{H}]^{+}=222.097$ $\mathrm{m} / \mathrm{z}\left(\right.$ red) and $[\mathrm{M}+\mathrm{H}]^{+}=294.118 \mathrm{~m} / \mathrm{z}$ (blue), respectively. 
bioRxiv preprint doi: https://doi.org/10.1101/2021.12.02.470905; this version posted December 2, 2021. The copyright holder for this preprint (which was not certified by peer review) is the author/funder. All rights reserved. No reuse allowed without permission.

\section{SUPPLEMENTAL MATERIAL}

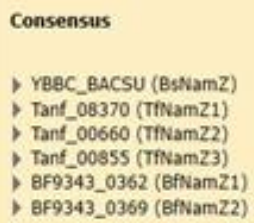

YBBC_BACSU (BsNamZ) - Tant_08370 (TiNamZ1) - Tant_00660 (TfNam22) - Tanf_0085s (TfNam23) 1) BF9343_0362 (BfNamZ1) - BF9343_0369 (BfNamZ2)

Consensus

- YBeC_BACSU (BsNamZ) Tant_08370 (TfNamZ1) - Tant_00660 (TfNamz2) - Tanf_00s5s (TfNam23) - BF9343_0362 (BfNamZ1) - BF9343_0369 (BfNam22)

Consensus

1. YBBC_BACSU (BsNamz) - Tant_08370 (TfWamZ1) - Tanf_00660 (TfNam22)

- Tant_o0s5s (TfNamz3)

- BF9343_0362 (BfNamz1)

- BF9343_0369 (BfNamZ2)

Consensus

- YBeC_BACSU (BsNamZ) - Tant_08370 (TfNamZ1)

- Tanf_00660 (TfNamz2)

- Tanf 00s5s (TfNamz3)

BE9343 0362 (effamz1)

- BF9343_0369 (BfNamz2)

Consensus

YBeC_BACSU (BsNamz) - Tanf_08370 (TfNamZ1) - Tanf_00660 (TfNamz2) - Tant_0085s (TfNam23)

BF9343_0362 (BfNamZ1)

1 BF9343_0369 (BfNamz2)

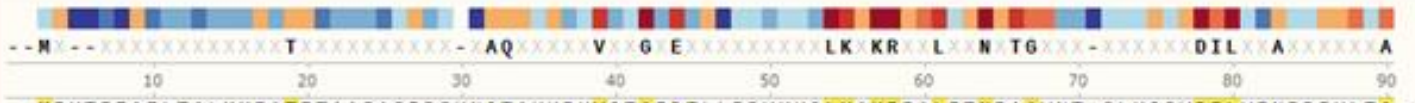

- - MRKTIFAFLTGLMMFGTITAASASPDSKNQTAKKPKVQTOIDTLLPOYKKQLKGKRIGLITNPAGVNT-SLKSSVDILYENPDIKLTA 87 ..... MKRIHIIVWCLCTL.......PVL-ATQAQKITIKT GLEVLKEQRFQCLKGKRTGLITNPTGVDN-HLRSTIDILHEAPEVNLTA 76 -MK - - RNIIAFFLFLTLCIAATGTVF - -AQQRNKRVVLGNERH-DSICTRLKDKRVALAVNHTSILETGFTHLLDTLL-AQKIDIRK 80 - MK - ...RNILSLFLLLMLWVSATGTIS - AQQRNKRVVPGNERM-DSICTRLKDKRVALAVNHTSILGTGFTHLLDTLL-AQKIDIRK BO MTYRRSILKLLLTFFVFMTSTLLSRGAEP-GARPPRIRIKTGIEVLKEQNFKCLEGKRVGLITNPTGVDN - HLISTIDILHEAPNVNLVA B8

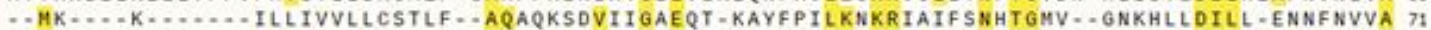

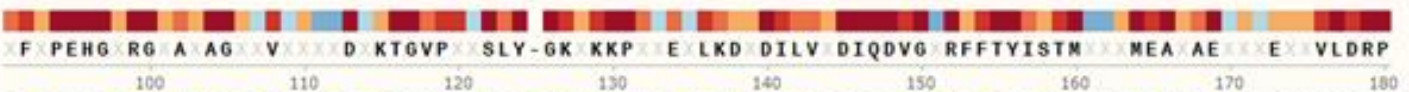

LFGPEHGVRGDAQAGDEVGSYIDEKT GVPVYSLY-GKTKKPTPEMLKNVDILMFDIQDVGTRFYTYIYTMAYAMEAAKENGIPFMVLORP 176 LYGPEHGVRGDVHAGOKIDSGTDPATGLPVYSLY-BATRKPTPEMLKDIDVLVYOIQDIGCRSFTYISTMGLAMEAAAENNIEFVVLDRP 16S VFAPEHGFRGTADAGATVHDSCDPKTGVPIVSVY-GKNKKPSAEQLADVDIVVFDIQDVGARFFTYISTMHYLMEACAEQGKELMVLDRP 169 VFAPEHGFRGTADAGATVHDSRDPKTOVLIVSVY-GKNKKPSAEQLADVDIIVFDIQDVGARFFTYISTMHYLMEACAEHGKELMVLNRP 169 LYGPEHOVRODVHAGOKVDNANDSSTOLPVYSLY-GKTRKPTPEMLKDIDVLVYDIQDI OCRSFTYISTMGVAMEAAAENNKEFIVLDRP I7? IFSPEHGFRGNADAGEHVSSTIDSKTGVPILSLYNGKSKKPSEASMKKFDILIVDIQDVGLRFYTYYISMVRLMDACAEYDRKILILDRP 16:

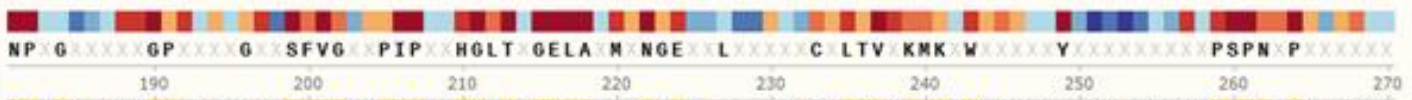

NPQGGNHIEGPILEPEYASFVGLYPIPLKHGMTI GELASLFNKEF ... SIDADLTVVKMKHWKRKMDFODTRLPFVLPSPNMPTVESTF 262 NPLGGLKIEGCIVEDGFFSFYSQYKIPYIYGLTCGELALMLNADKQP . . GKACKL HYYKMKGWKRKMOYTQTGLOWIPPSPHIPHAHSAF 253 NPN - DYYDGPVRQPGFESFVGVHPIPVLHGLTVGELAQHINGEGWLPSAATCKLTVIKMLNWQHGDAYQ ....PTVRPSPNLPNDQAIR 253 NPN - - DYVDGPVRQPGFESFVGVHPIPVLHGLTVGELAQHINGEGWLPSAATCKLTVIKMLNGQHGDAYQ.... - PTVRPSPNLPNDQAVR 253 NPIGOLKIEONVVEDGYISFVSQFKIPYLYOLTCOELALMLNGEQML - SKPCNLHVVKMKOWKRKMDYVQTGLQWIPSSPHIPHPHSAF 265 NPNG - HYVDGPILDMKYKSGVGGLPIPIVHGMTL GELALMVNGERWLPSSRICDVTVIPCKNYTHQTMYR .... LPIPPSPNLPNMKAIY 246

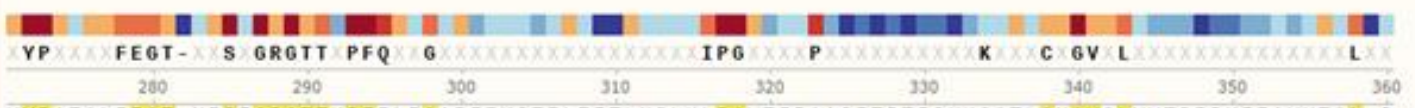

VYPATGLIEGT-NISEGRGTTKPFELIGAPFIKSTELEETLNSLHLPGVTFRAASFTPTFSKHQGTLCHOVQLYVTDRDKFEAVKTGL-S 350 FYPVSGIFGELGYASI GVGYTIPFQMFAAPWIKAAELTRRMNALRIPGVNFRPIHLKPFYATNKGEFIQGVQVHITDYRQASLSDIQF-L 342 LYPSLCFFEGT-CMSVGRGTHFPFQIVGYTLPQTGSFT - .FVPTAIPGMDTAPL ........ YKDKTCYGDDLRYY . . .PFAGGLTLSF 328 LYPSLCFFEOT - CMSVGRGTHFPFQIVGYTLPQTGSFT _. FVPTAIPGMDTAPL ......... YKDKTCYGDDLRYY ....PFAGGLTLSF 323 FYPVSOILGELOYMSIOVGYTIPFOMFAARWVEAEKLADNLNRLHLPGVIFRPMHLKPFYSVGKEEHLQGVQVHIVDFNKASLSEIOF-Y 354 LYPSICLFEGT-PVSLGRGTTLPFQVYGHPNMTGYNYN - . FTPRSIPGAKNPPQ ......... - NKLCHGVNLSNLSDEEIWKKGINLDY 324

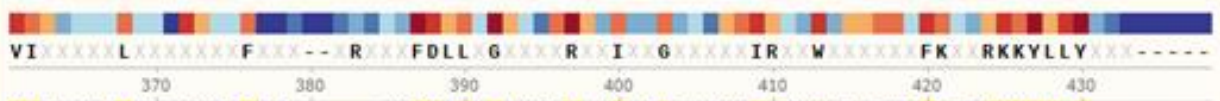

VIKTIHDLYP-EDFEFLST ...... GSFDKLAGNGWIRTKIENGTSVENIINSYEKTLQQFSKTRKKYLIY........ 414 VMQEIAALYP - ORAVFAHADSTRFRMFOKVCGSNRIREGFIRRNRWEDVRPYWYKDVEQFKKQSKKYYLYP . . . . . 413 VIDFFARTGRNEKLFF...... NRPRWFDLLAGTDALRKQILAGVPEAEIRATWQSGLDEYKQMRKKYLLYPDYPVOE. 401 VIDFFARTGRNEKLFF...... NRPRWFDLLAGTDALRKQILDGVPEAEIRATWQSGLDEYKQIRKKYLLYPDYPEAE. 401 VMQEVTALYP - DRAVFDHADKERFHMFDLVSOSKE IRERFSQRNRWEDVRDYWYKDVDDFRRLSQKYYLYK ...... LIOAYHNLNMGDRFF.......... RPFFELLVGTOYVRKMIEGGKSADEIKARWKRDVERFKIQRKPYLLYQON ..... 399

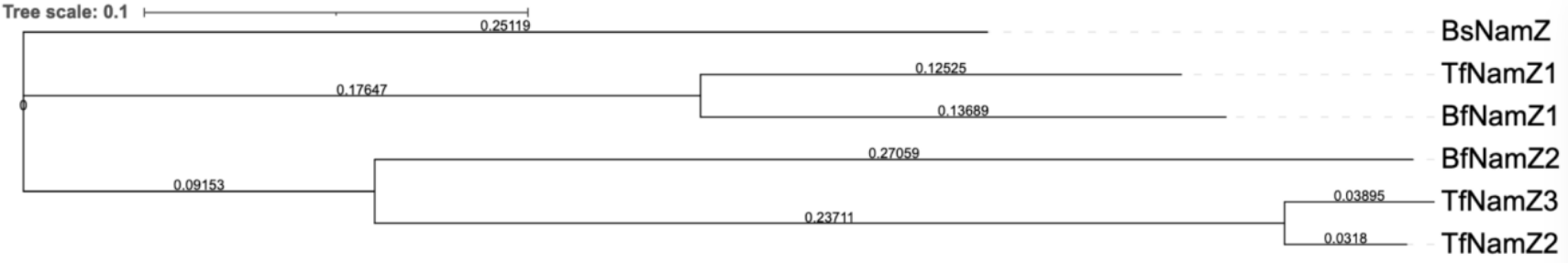

FIG. S1. Multiple amino acid sequence alignment and neighbor-joining tree of NamZ orthologs from B. subtilis 168 (BsNamZ), B. fragilis ATCC 9343 (BfNamZ1 and BfNamZ2) and T. forsythia 
ATCC 43037 (TfNamZ1, TfNamZ2, TFNamZ3). The alignment was conducted with Clustal Omega and was visualized with the SnapGene multiple alignment tool. The phylogenetic, neighbor-joining tree was constructed with iTOL version 6.4 [Letunic, 2021 \#20026])

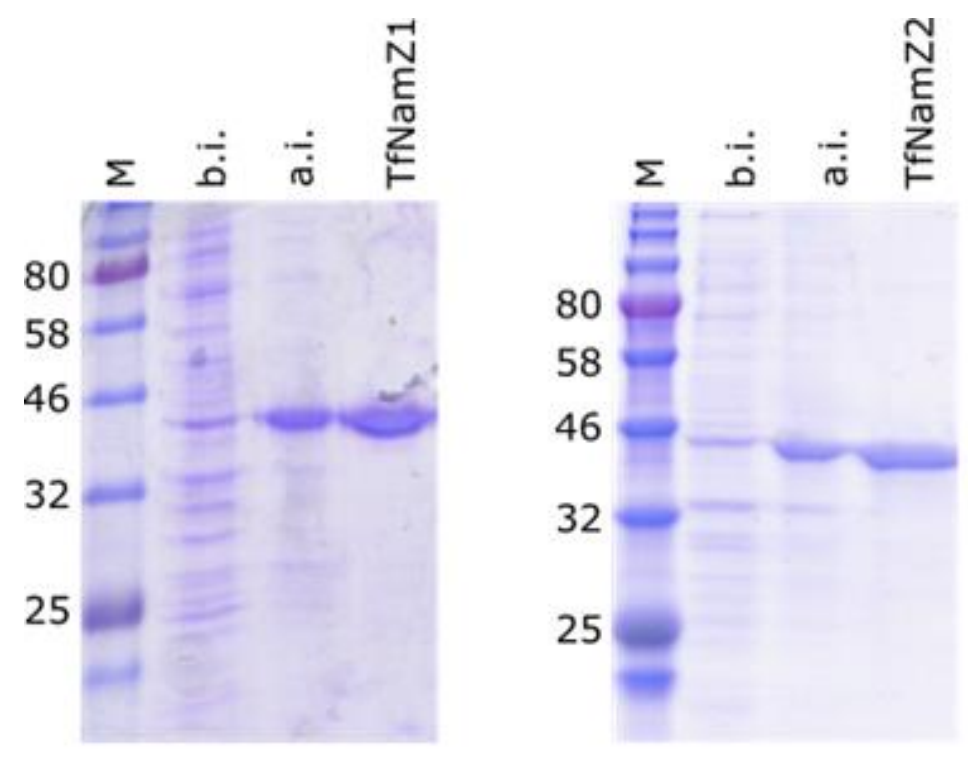

FIG. S2. SDS-PAGE analysis of TfNamZs. Expression and purity of the recombinant proteins TfNamZ1 and TfNamZ2 were analyzed by SDS-PAGE with Coomassie brilliant blue staining. Lane 1, protein molecular weight marker (M, size in $\mathrm{kDa}$ ); lane 2, E. coli cell extract before IPTG induction (b.i.), lane 3, after IPTG induction and overnight incubation at $18{ }^{\circ} \mathrm{C}$ (a.i.); lane $4,5 \mu \mathrm{g}$ of $\mathrm{TfNamZ}$ recombinant proteins after purification by $\mathrm{Ni}^{2+}$-affinity chromatography and size exclusion chromatography. 


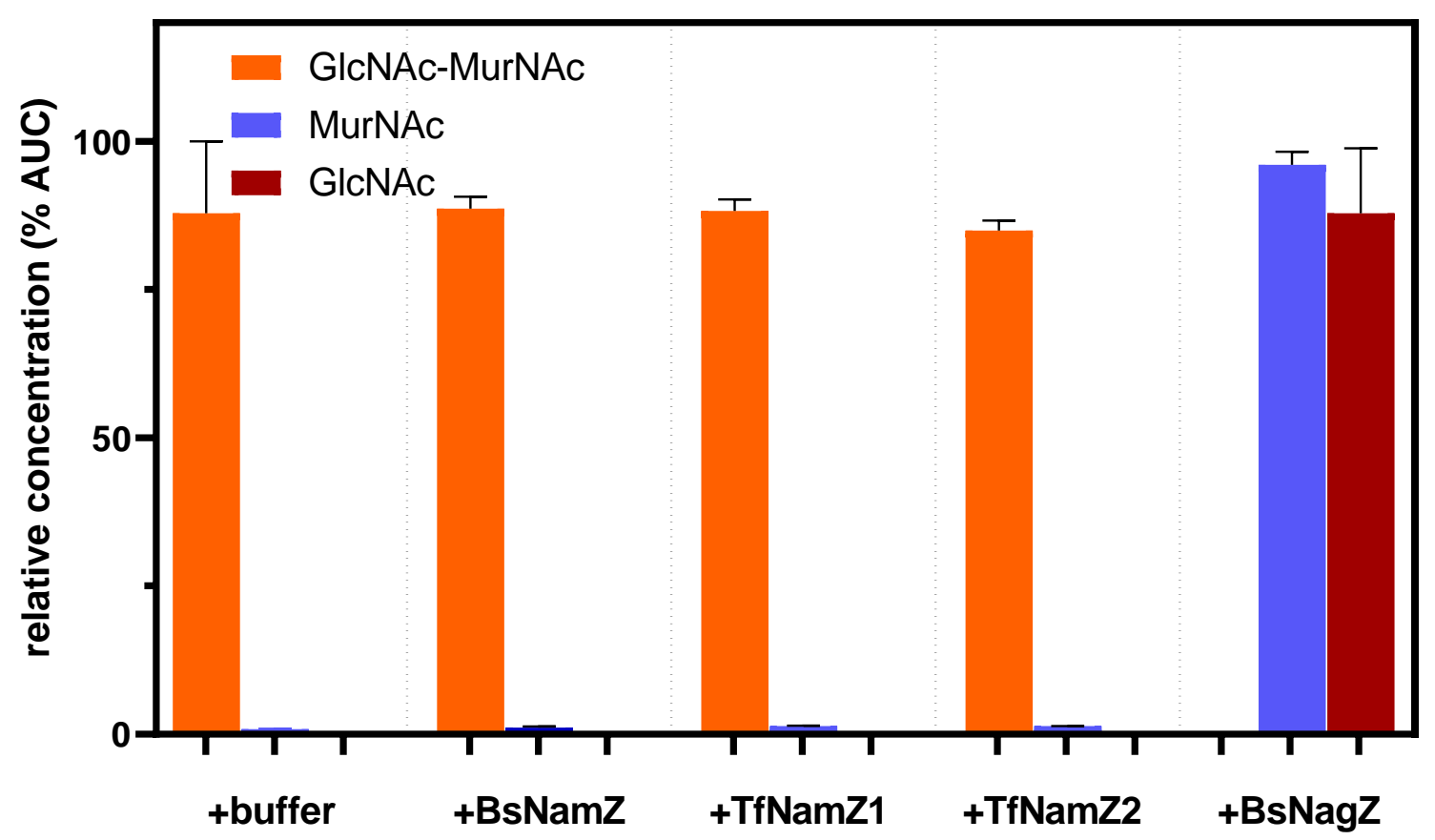

FIG. S3. Commercial GIcNAc-MurNAc was incubated with buffer, BsNagZ (positive control),

BsNamZ, TfNamZ1 or TfNamZ2 enzymes. Overnight reactions were heat inactivated and the supernatants were analyzed for the presence of GlcNAc-MurNAc (orange), MurNAc (blue) and GlcNAc (red) by HPLC-MS analysis. The exact monoisotopic masses $[\mathrm{M}]$ of the proton adduct $[\mathrm{M}+\mathrm{H}]^{+}$of the investigated peptidoglycan sugar metabolites MurNAc-GlcNAc, MurNAc and GlcNAc are summarized in Table S3. Data from three biological replicates are presented as areas under the curve from the extracted ion chromatograms (EICs) of the respective compounds and are presented in \%. GlcNAcMurNAc was completely degraded by BsNagZ but, as expected, BsNamZ as well as the TfNamZs enzymes failed to show $\beta$ - $N$-acetylglucosaminidase activity. 

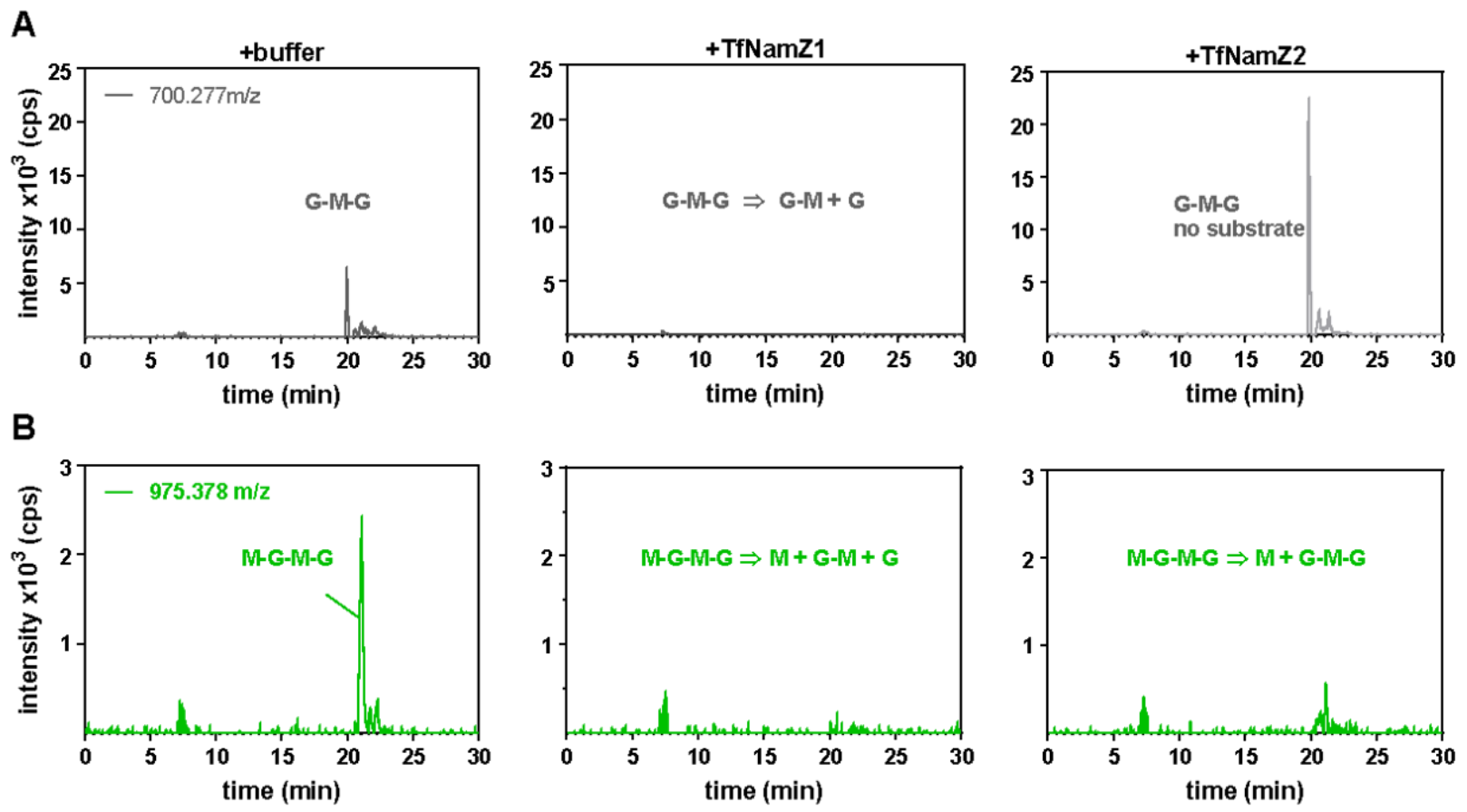

FIG. S4. TfNamZ1 and TfNamZ2 show differences in substrate specificity with oligomeric PGN.

The peptide-free PGN glycan mixture from S. aureus, generated by Atl-digestion as described in Figure 4, contains minor amounts of the trisaccharide GlcNAc-MurNAc-GlcNAc (G-M-G; A) and the tetrasaccharides MurNAc-GIcNAc-MurNAc-GIcNAc (M-G-M-G; B), besides the main product MurNAc-GlcNAc. Incubation with the enzymes revealed that TfNamZ1 cleaves both oligosaccharides, whereas TfNamZ2 only cleaves M-G-M-G. While TfNamZ2 cleaves only the MurNAc-moiety from the non-reducing end of M-G-M-G, yielding G-M-G, this product is further cleaved by TfNamZ1, yielding MurNAc-GIcNAc (M-G) and GIcNAc (G) (as indicated). Data are presented as EICs for the trisaccharide GlcNAc-MurNAc-GlcNAc, G-M-G in grey, $\left([\mathrm{M}+\mathrm{H}]^{+}=700.277 \mathrm{~m} / \mathrm{z}\right)$ and for the tetrasaccharide MurNAc-GlcNAc-MurNAc-GlcNAc in green $\left([\mathrm{M}+\mathrm{H}]^{+}=975.378 \mathrm{~m} / \mathrm{z}\right)$, and are shown as intensity x $10^{3}$ (cps). 

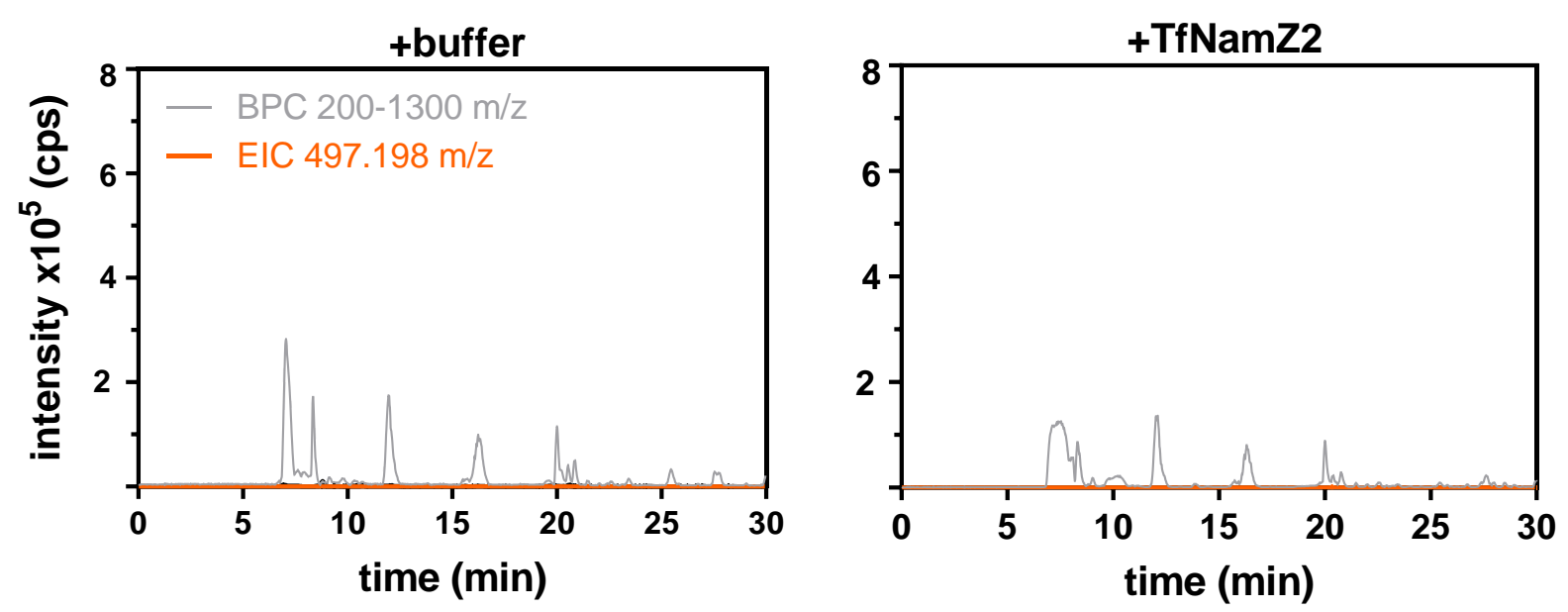

FIG. S5. B. subtilis glycan strands are not cleaved by TfNamZ2. B. subtilis glycan strands were generated as described in Figure 5. Data are presented as base peak chromatograms (BPC) 200-1300 m/z in gray and as extracted ion chromatogram (EIC) of $[\mathrm{M}+\mathrm{H}]^{+}=497.198 \mathrm{~m} / \mathrm{z}$, corresponding to GlcNAcMurNAc (in orange) and are plotted as intensity x $10^{5}$ counts per second (cps). 

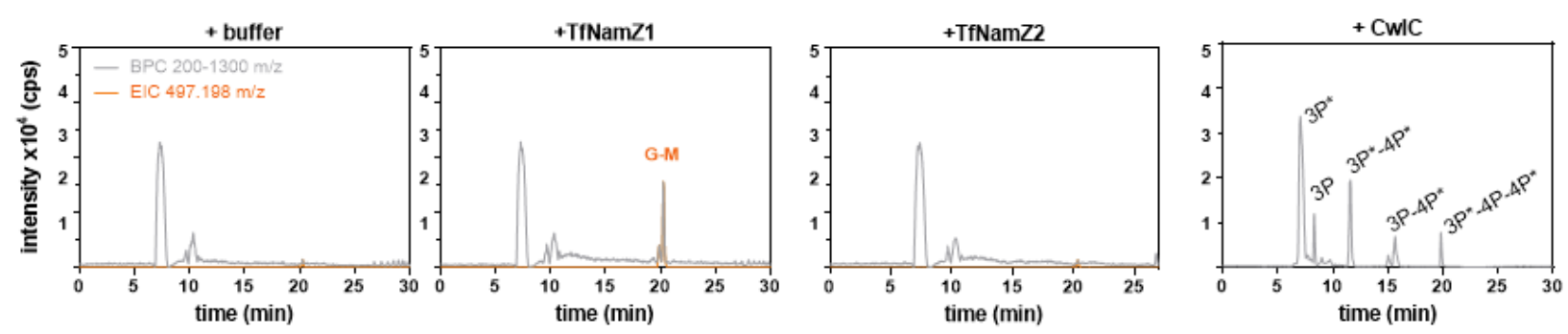

FIG. S6. Substrate specificity of TfNamZ1 and TfNamZ2 with B. subtilis PGN sacculi. PGN sacculi

from B. subtilis were incubated with TfNamZ1, TfNamZ2, the amidase BsCwlC, or buffer as a control.

Samples were analyzed by HPLC-MS and the data are presented as base BPCss 200-1300 m/z (gray lines) and as extracted ion chromatogram (EIC) for GlcNAc-MurNAc (orange, $[\mathrm{M}+\mathrm{H}]^{+}=497.198 \mathrm{~m} / \mathrm{z}$ ).

The peptide products after CwlC digestion were identified by LC-MS according to their exact masses as:

3P-tripeptide, 3P*-tripeptide amidated; 4P-tetrapeptide, 4P*-tetrapeptide amidated. 


\section{Supplementary Tables}

Table S1. Oligonucleotides used in this study

\section{Primer name}

Tanf_08370/namZ1_ss Ndel Fw

Tanf_08370/namZ1 XhoI Rev

Tanf_00660/namZ2_ss NdeI Fw

Tanf_00660/namZ2 XhoI Rev

Tanf_00855/namZ3-ss NdeI Fw

Tanf_00855/namZ3 XhoI Rev

restriction sites are underlined

\author{
Primer sequence: \\ AGTCACATATGACACAGGCACAAAAGATCACGATCAAGACAGG \\ AGT CACTCGAGTGGATAGAGGTAATATTTTTTCGACTG \\ CGGTCATATGCAACAGCGGAACAAGCG \\ GATTTACTCGAGTTCCCCCACCGGATAGTCCG \\ CAGCATATGCAACAGCGGAACAAGCG
}

AAAACTCGAGCTCTGCTTCGGGGTAGTCCG

Table S2. Strains and plasmids used in this study

\author{
Strains and plasmids \\ Strains \\ B. subtilis 168 \\ S. aureus USA300 JE2 \\ E. coli $\mathrm{DH} 5 \alpha$ \\ E. coli BL21(DE3)

\section{Plasmids} \\ pET29b \\ pET29b-BsnamZ (ybbC) \\ pET29b-TfnamZ1 (Tanf_08370) \\ pET29b-TfnamZ2 (Tanf_00660) \\ pET29b-TfnamZ3 (Tanf_00855) \\ pET28a \\ pET28a-BscwlC (BSU17410) \\ pET28a-atl $\mathrm{Glc}\left(S A U S A 300 \_0955\right)$ \\ pET16b-BsnagZ (ybbD)
}

\section{Genotype and cloning strategy}

$\operatorname{trp} C 2$, sequenced B. subtilis parental strain

USA300 LAC, cured for 3 plasmids for antibiotic resistance

$F^{-}$endA1 glnV44 thi-1 recAl relA1 gyrA96 deoR nupG purB20 $\varphi 80$ dlacZAM15 $\triangle\left(\right.$ lacZYA-argF)U169, hsdR17( $r_{K}$ $\left.m_{K}^{+}\right), \lambda^{-}$

E. coli str. B $F^{-}$ompT gal dcm lon $h s d S_{B}\left(r_{B^{-}} m_{B^{-}}\right) \lambda(D E 3$ [lacI lacUV5-T7p07 ind1 sam7 nin5]) $\left[\mathrm{malB}^{+}\right]_{K-12}\left(\lambda^{S}\right)$

E. coli expression vector, $\mathrm{Kan}^{\mathrm{R}}$

IPTG inducible cytoplasmic NamZ-His6 expression vector, $\operatorname{Kan}^{\mathrm{R}}$

IPTG inducible cytoplasmic TfNamZ1-His6 expression vector, $\operatorname{Kan}^{\mathrm{R}}$

IPTG inducible cytoplasmic TfNamZ2-His6 expression vector, $\mathrm{Kan}^{\mathrm{R}}$

IPTG inducible cytoplasmic TfNamZ3-His6 expression vector, $\operatorname{Kan}^{\mathrm{R}}$

E. coli expression vector, $\mathrm{Kan}^{\mathrm{R}}$

IPTG inducible cytoplasmic CwlC-His6 expression vector, $\mathrm{Kan}^{\mathrm{R}}$

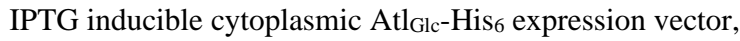
$\mathrm{Kan}^{\mathrm{R}}$

IPTG inducible cytoplasmic $B s \mathrm{NagZ}$-His10 expression vector, $A m p^{R}$

\section{Reference or source}

Bacillus Genetic Stock Center

Nebraska Transposon mutant library

New England Biolabs

New England Biolabs

Novagen

[Müller, 2021]

this study

this study

this study

Novagen

[Müller, 2021]

[Müller, 2021]

[Litzinger, 2010]

Kan- kanamycin, Amp-ampicillin 
Table S3. Exact monoisotopic mass $[\mathrm{M}]$ and the monoisotopic mass of the proton adduct $[\mathrm{M}+\mathrm{H}]^{+}$of relevant PGN carbohydrates

$\begin{array}{llll}\text { Name } & \text { Formula } & \text { Exact monoisotopic mass [M] } & \text { [M] of the proton adduct [M+H] }^{+} \\ \text {GlcNAc } & \text { C8H15NO6 } & 221.0899 & 222.0972 \\ \text { MurNAc } & \text { C11H19NO8 } & 293.1111 & 294.1183 \\ \text { GlcNAc-MurNAc } & \text { C19H32N2O13 } & 496.1904 & 497.1977 \\ \text { MurNAc-GlcNAc } & \text { C19H32N2O13 } & 496.1904 & 497.1977 \\ \text { GlcN-MurNAc } & \text { C17H30N2O12 } & 454.1799 & 455.1872 \\ \text { GlcNAc-MurNAc-GlcNAc } & \text { C27H45N3O18 } & 699.2698 & 700.2771 \\ \text { MurNAc-GlcNAc-MurNAc } & \text { C30H49N3O20 } & 771.2909 & 772.2982 \\ \text { MurNAc-GlcNAc-MurNAc-GlcNAc } & \text { C38H62N4O25 } & 974.3703 & 975.3776\end{array}$

\section{References}

Letunic I, Bork P. 2021. Interactive Tree Of Life (iTOL) v5: an online tool for phylogenetic tree display and annotation. Nucleic Acids Res 49:W293-W296.

Müller M, Calvert M, Hottmann I, Kluj RM, Teufel T, Balbuchta K, Engelbrecht A, Selim KA, Xu Q, Borisova M, Titz A, Mayer C. 2021. The exo- $\beta$-N-acetylmuramidase NamZ from Bacillus subtilis is the founding member of a family of exo-lytic peptidoglycan hexosaminidases. J Biol Chem 296:100519.

Litzinger S, Fischer S, Polzer P, Diederichs K, Welte W, Mayer C. 2010. Structural and kinetic analysis of Bacillus subtilis $\mathrm{N}$-acetylglucosaminidase reveals a unique Asp-His dyad mechanism. J Biol Chem 285:35675-33584. 